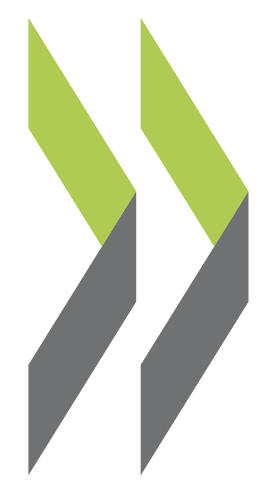

OECD Economics Department Working Papers No. 526

\title{
Strengthening \\ the Integration of Japan in the World Economy to Benefit more Fully from Globalisation
}

Randall S. Jones, Taesik Yoon 
Organisation de Coopération et de Développement Economiques

ECONOMICS DEPARTMENT

STRENGHTENING THE INTEGRATION OF JAPAN IN THE WORLD ECONOMY TO BENEFIT MORE FULLY FROM GLOBALISATION

ECONOMICS DEPARTMENT WORKING PAPER No. 526

by Randall S. Jones and Taesik Yoon

All Economics Department Working Papers are available through OECD's Internet Website at http://www.oecd.org/eco/working_papers 


\section{ABSTRACT/RÉSUMÉ \\ Strengthening the integration of Japan \\ in the world economy to benefit more fully from globalisation}

Globalisation through international trade, foreign direct investment (FDI) and international movements of labour is a key force driving economic growth. However, Japan is an outlier among OECD countries, with the lowest levels of import penetration, stock of inward FDI relative to GDP and foreign workers as a share of employment, reflecting the legacy of policies during its post-war development. Policy reforms would help Japan make greater use of goods, services, capital, technology and human resources from abroad. Given the close links among trade, investment and labour flows, it is important to pursue a comprehensive approach, including; i) reducing barriers to FDI and imports, particularly in agriculture, through multilateral trade negotiations and regional trade agreements; ii) relaxing product market regulations, notably in the service sector; iii) fully opening the M\&A market to foreign firms; and iv) easing controls on the inflow of foreign workers, including those in non-technical occupations.

This Working Paper relates to the 2006 Economic Survey of Japan (www.oecd.org/eco/surveys/japan).

JEL classification: F1, F21, F22, F23

Keywords: Globalisation, foreign direct investment (FDI), mergers and acquisitions, international trade, import penetration, trade liberalisation, regional trade agreements, Economic Partnership Agreements, agricultural trade, immigration, foreign workers, Japan.

\section{$* * * * * * *$ \\ Renforcer l'intégration du Japon dans \\ l'économie mondiale afin de profiter plus pleinement de la mondialisation}

La mondialisation qui s'opère par le biais du commerce international, de l'investissement direct étranger (IDE) et des flux internationaux de ressources humaines est un moteur essentiel de la croissance économique. Cependant, le Japon est un cas à part parmi les pays de l'OCDE, se classant au dernier rang du point de vue de la pénétration des importations, de la part de l'IDE dans le PIB et de la proportion de travailleurs étrangers dans l'emploi, autant d'héritages des politiques menées au cours de son développement après la guerre. Des réformes aideraient le Japon à mieux exploiter les ressources que constituent les biens, les services, les capitaux, la technologie et la main-d'œuvre de provenance étrangère. Compte tenu des liens étroits qui unissent les flux d'échanges, d'investissement et de main-d'œuvre, il importe d'adopter une approche globale consistant à i) réduire les obstacles à l'IDE et aux importations, en particulier dans l'agriculture, par le biais de négociations commerciales multilatérales et d'accords commerciaux régionaux, ii) assouplir la réglementation des marchés de produits, notamment dans le secteur des services, iii) ouvrir complètement le marché des fusions-acquisitions aux entreprises étrangères; et $i v$ ) assouplir les contrôles sur l'entrée de travailleurs étrangers, notamment dans les professions non techniques.

Ce Document de travail se rapporte à l'Étude économique du Japon 2006 (www.oecd.org/eco/etudes/japon).

Classification JEL : F1, F21, F22, F23

Mots clés: Mondialisation, investissement direct étranger (IDE), fusions et acquisitions, échanges internationaux, pénétration des importations, libéralisation des échanges, d'accords commerciaux régionaux, accords de partenariat économique, commerce agricole, immigration, Japon.

\section{Copyright OECD 2006}

Application for permission to reproduce or translate all, or part of, this material should be made to: Head of Publications Service, OECD, 2 rue André-Pascal, 75775 Paris Cedex 16, France. 


\section{TABLE OF CONTENTS}

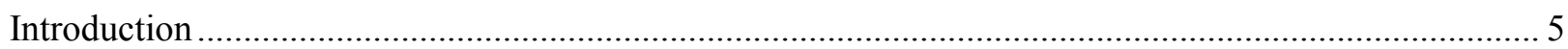

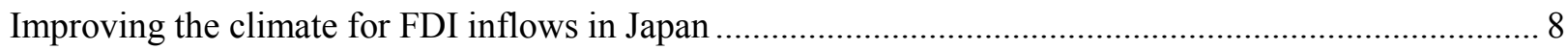

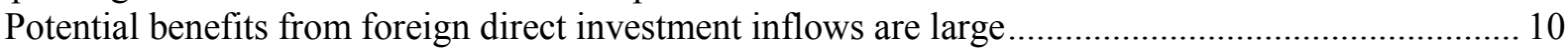

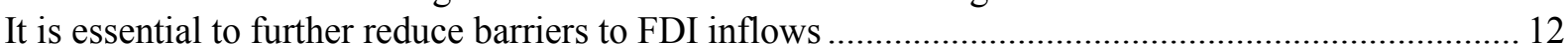

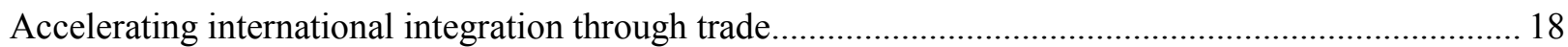

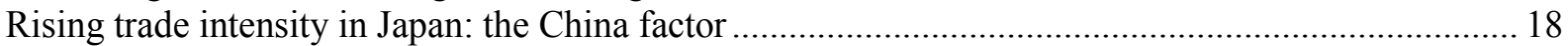

Japan's level of import penetration remains the lowest in the OECD area .......................................... 19

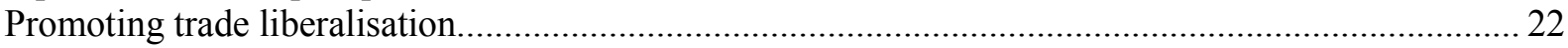

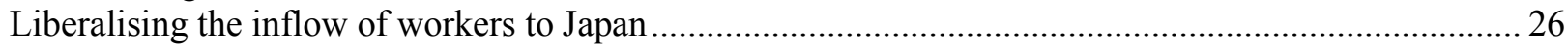

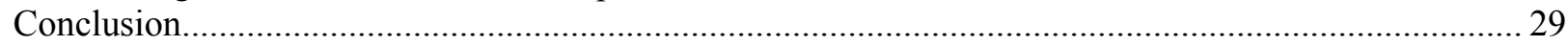

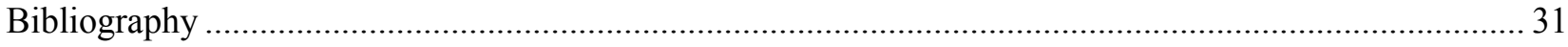

\section{Tables}

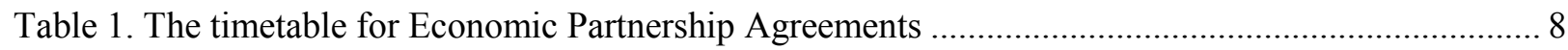

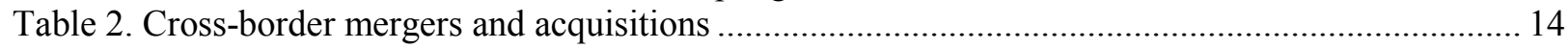

Table 3. The proportion of stable shareholders in listed companies ...................................................... 16

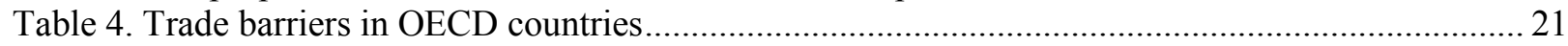

Table 5. Overview of Japan's regional trade agreements and expected economic impact ...................... 23

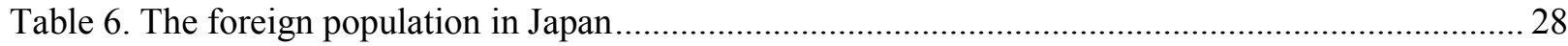

\section{Figures}

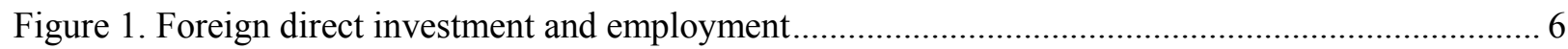

Figure 2. Inward FDI in Japan and its share of the world total .......................................................... 9

Figure 3. Labour productivity of foreign affiliates relative to the national average .............................. 10

Figure 4. International comparison of inward foreign direct investment positions.................................. 11

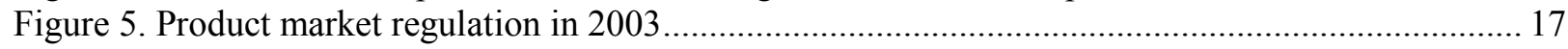

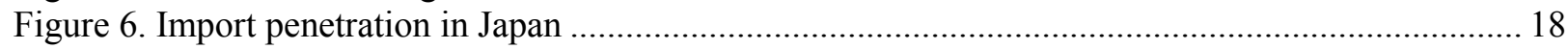

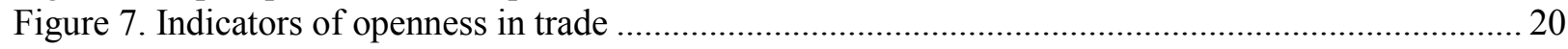

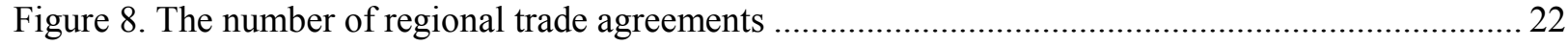

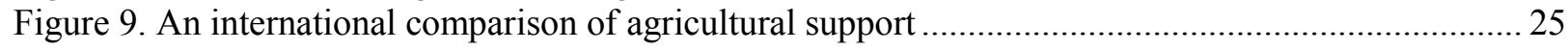

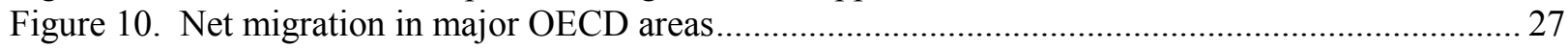

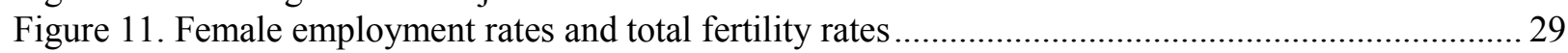




\section{$\mathrm{ECO} / \mathrm{WKP}(2006) 54$}

\section{Boxes}

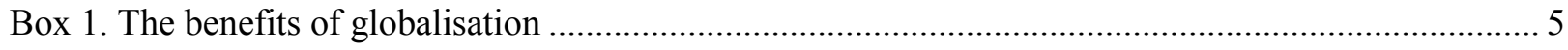

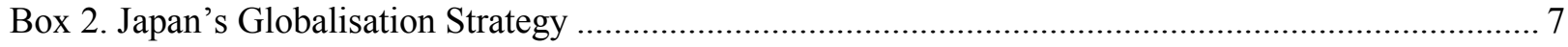

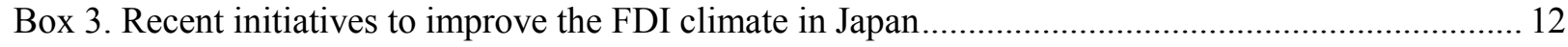

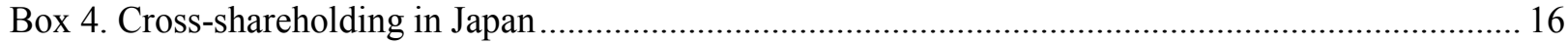

Box 5. Summary of recommendations to strengthen integration in the world economy .......................... 30 
ECO/WKP(2006)54

\title{
STRENGTHENING THE INTEGRATION OF JAPAN IN THE WORLD ECONOMY O BENEFIT MORE FULLY FROM GLOBALISATION
}

\author{
by Randall S. Jones \& Taesik Yoon ${ }^{1}$
}

\section{Introduction}

1. Economic theory and history demonstrate the benefits of integration in the world economy (Box 1). The process of globalisation is being driven through various channels, notably foreign direct investment (FDI), trade in goods and services, labour flows between countries and technology transfers. For Japan, the steady rise in its share of world trade until the 1990s was a key aspect of its rapid post-war development. At the same time, explicit rules restricting inflows of goods and investment, aimed at promoting and protecting local companies and industries, limited the degree of integration in the world economy. In addition, product market regulation had a negative effect on imports of goods and services and inflows of FDI. The impact of government policies may have been re-enforced by elements of Japan's unique economic system, such as lifetime employment, stable cross-shareholding, keirestu and the main bank system, which may have created additional entry barriers to the Japanese economy.

\section{Box 1. The benefits of globalisation}

In addition to tariff and non-tariff barriers and FDI restrictions, domestic product market regulations can hinder international flows of goods and investment by distorting relative prices. This also distorts the relative rates of return from investing in different locations, even when regulations do not discriminate between local and foreign firms (Nicoletti et al., 2003). Removing such barriers to globalisation strengthens competition, leading to both static and dynamic gains. Static gains arise from better allocation of existing resources in line with a country's comparative advantage. In addition, increased competition strengthens pressure on firms to operate more efficiently. Dynamic gains result from greater efforts to innovate and optimise production, and from more rapid diffusion of new technology, which is stimulated by openness to trade and investment (see the 2006 OECD Economic Survey of Japan). Moreover, firms are able to realise increasing returns to scale as larger markets allow them to expand production.

A recent OECD study estimated that GDP per capita in member countries would increase by between 2 and $5 \%$ if all external and internal barriers were reduced to the level in the least restrictive member country. Product market reforms were estimated to have the largest impact, increasing GDP per capita by 1.75 to $3.0 \%$, with another 0.25 to $1.0 \%$ from cutting tariff rates and $0.75 \%$ from lowering restrictions to FDI. In the case of Japan, the gains in GDP per capita were estimated to be $4.4 \%$, including $2.4 \%$ from regulatory reforms, $1.3 \%$ from bilateral tariff reductions and $0.7 \%$ from reductions in FDI restrictions (OECD, 2005a). In addition to these static gains, liberalisation would produce dynamic gains by stimulating R\&D, innovation and technological progress on a sustained basis. Although there is much uncertainty about the size of dynamic gains, empirical research suggests that they could be quite large.

There have been concerns in Japan about the "hollowing out" of its manufacturing sector, even though its share of GDP has fallen only slightly from 22 to $20 \%$ over the past decade. FDI outflows are sometimes identified as a factor contributing to this decline. Employment in the foreign affiliates of Japanese parent companies in the manufacturing sector reached 2 million in 2002, equivalent to $16 \%$ of Japan's domestic manufacturing employment. Japan's overseas employment thus ranks in the middle of the 12 OECD countries for which data are available (Figure 1). In contrast, the 0.2 million workers employed by foreign affiliates operating in Japan is exceptionally low compared to 1.8 million in the United States and 1 million in Germany. This amounts to only $1 \%$ of manufacturing employment in Japan, the lowest

1. Randall S. Jones is head of the Japan/Korea Desk in the Economics Department of the OECD and Taesik Yoon is an economist on that desk. This paper is based largely on material from the OECD Economic Survey of Japan published in July 2006 under the authority of the Economic and Development Review Committee (EDRC). The authors would like to thank Andrew Dean, Val Koromzay, Willi Leibfritz and Tadashi Yokoyama for valuable comments on earlier drafts. Special thanks go to Roselyne Jamin for technical assistance and to Nadine Dufour for technical preparation. 
among member countries surveyed (Panel B). Reforms to remove or relax obstacles to FDI inflows would provide significant economic gains for Japan, as discussed below.

Figure 1. Foreign direct investment and employment Per cent of domestic manufacturing employment, $2002^{(1)}$

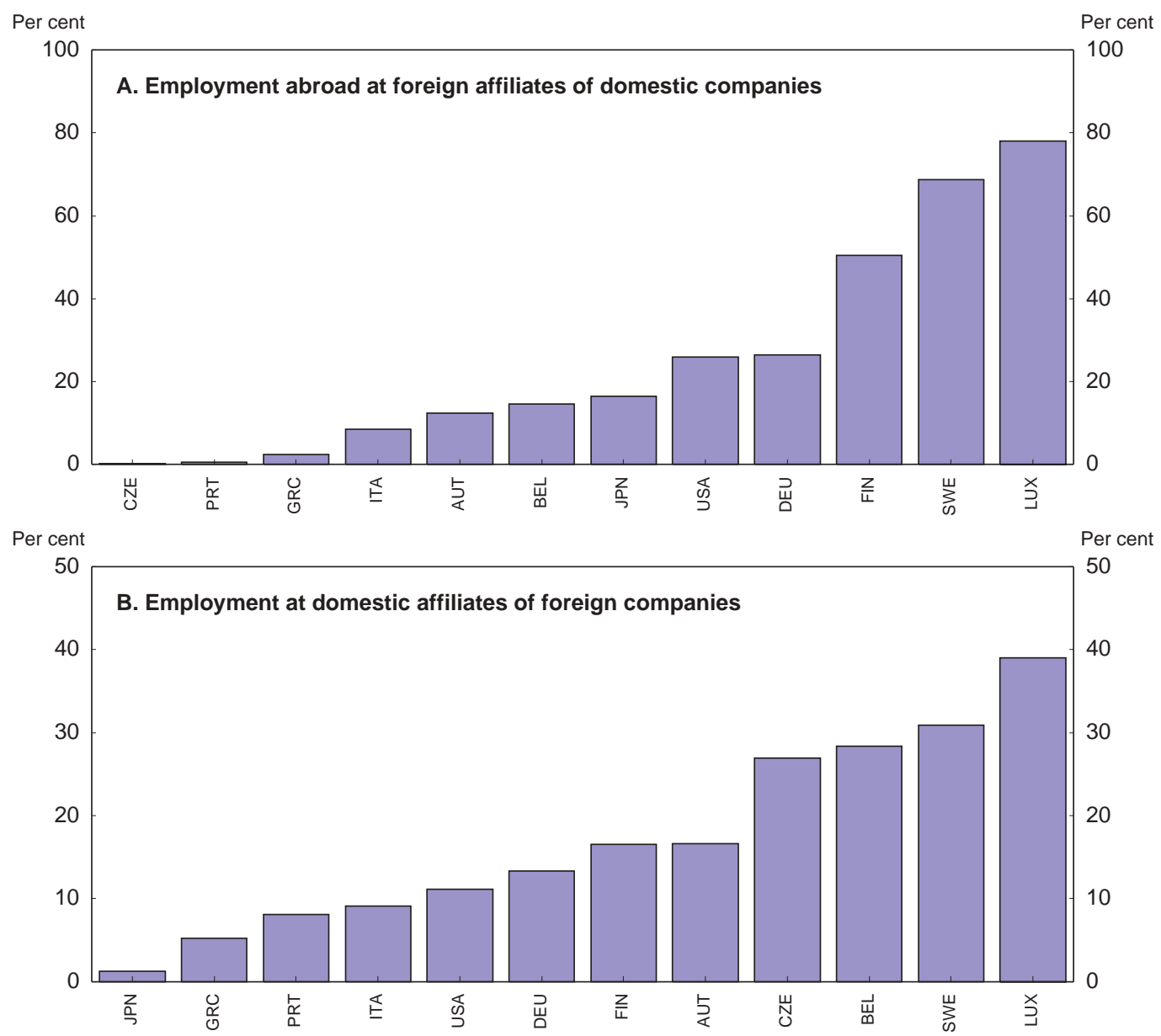

1. 2001 for Japan, Sweden, Austria and Portugal; 1999 for Italy and Luxembourg. Source: OECD (2005c), OECD Economic Globalisation Indicators, 2005 and STAN database.

2. Since the collapse of the bubble in the early 1990s, Japan has accelerated its efforts to open further to the world economy by relaxing explicit restrictions on trade and investment, while pursuing reforms that lower implicit obstacles to foreign entry. The emphasis on closer integration with the world economy prompted the Council on Economic and Fiscal Policy ${ }^{2}$ to present a "Globalisation Strategy" in 2006 (Box 2). While Japan's level of integration has increased, it still remains low by OECD standards in terms of FDI inflows, imports of goods and services and the number of foreign workers. Indeed, the stock

2. The Council on Economic and Fiscal Policy is the key policy making institution in the government. It is chaired by the prime minister and includes five key economic ministers, the governor of the Bank of Japan and four private-sector experts. 
of inward FDI and imports as a share of GDP and foreign workers in the labour force are all the lowest in the OECD area. This paper discusses how Japan can increase its openness to FDI, trade and human resources and thereby accelerate productivity and growth. It concludes with policy recommendations shown in Box 5.

\section{Box 2. Japan's Globalisation Strategy}

In May 2006, the Council on Economic and Fiscal Policy (CEFP) published a "Globalisation Strategy" that aims at enhancing Japan's international competitiveness. This is to be accomplished by accelerating domestic reforms to raise productivity and by making full use of goods, services, capital, technology, information and human resources from abroad. In launching this initiative, the prime minister stressed that Japan has benefited greatly from globalisation. The report includes a wide range of proposals to increase such benefits:

A. Improve and expand human resources

- Establish an environment that attracts outstanding talent from other countries, including researchers and students.

- Improve the immigration system in order to increase the inflow of highly qualified human resources.

- Consider relaxing immigration restrictions in non-technical services, such as long-term nursing care, to cope with population ageing.

- Upgrade domestic human resources by improving the education system, with a goal of raising international test scores to the world's top level by 2010.

B. Strengthen international competitiveness

- $\quad$ Raise efficiency in agriculture, with the aim of doubling the amount of agricultural exports by FY 2009.

- Implement the third Basic Plan for science and technology (see Chapter 5 of the 2006 OECD Economic Survey of Japan).

- Double the stock of inward foreign direct investment to 5\% of GDP by 2010.

C. Strengthen the global competitiveness of regions in Japan

- $\quad$ Create multicultural societies in Japan's regions.

- Increase the number of foreign tourists to Japan to 10 million by 2010.

D. Foreign policy and contribution to international society

- Accelerate negotiations of Economic Partnership Agreements (EPAs) in line with the timetable (Table 1), which is expected to expand the share of trade with EPA partners to more than $25 \%$ by 2010 at the latest.

- $\quad$ Create an East Asian Economic Zone.

- Work toward an OECD-style international system to provide policy advice and co-ordination in East Asia.

- Reform Overseas Development Assistance to boost its efficiency, while increasing outlays, including debt forgiveness, by $\$ 10$ billion over the period 2005 to 2009.

- Pursue a strategic energy policy that includes raising energy efficiency by $30 \%$ and lowering the oil dependency ratio to below $40 \%$ by 2030 .

E. Japan in the world in 2010

- Concentrate resources so as to maintain Japan's highly competitive position as a front-runner in global industry.

- It is expected that: i) the trade surplus will be maintained; ii) the service trade deficit, including travel services, will decline; and iii) the investment income surplus will expand. 
Table 1. The timetable for Economic Partnership Agreements Status and goals as of June 2006

\begin{tabular}{|c|c|c|}
\hline Country & Status & Goal \\
\hline Malaysia & Signed in 2005 & Aim to put into effect as early as possible in 2006 \\
\hline Thailand & Agreed on major points in 2005 & Aim to sign as early as possible \\
\hline Philippines & Agreed on major points in 2004 & Aim to sign as early as possible in 2006 \\
\hline Indonesia & Started negotiations in 2005 & Aim to agree on major points in 2006 \\
\hline $\begin{array}{l}\text { ASEAN as a } \\
\text { whole }\end{array}$ & Started negotiations in 2005 & Aim to complete negotiations by 2007 \\
\hline $\begin{array}{l}\text { Republic of } \\
\text { Korea }\end{array}$ & $\begin{array}{l}\text { Started negotiations in } 2003 \text { but } \\
\text { stopped since } 2004\end{array}$ & Continue to make efforts to resume the negotiations \\
\hline Chile & Started negotiations in 2006 & Aim to agree on major points in 2006 \\
\hline Singapore & $\begin{array}{l}\text { Signed and took effect in } 2002 \\
\text { The negotiation for a partial revision } \\
\text { of the EPA was agreed in } 2006\end{array}$ & $\begin{array}{l}\text { Aim to agree on major points as early as possible, } \\
\text { considering the progress of negotiations between } \\
\text { Japan and ASEAN }\end{array}$ \\
\hline Vietnam & $\begin{array}{l}\text { The first Joint Study Group (JSG) } \\
\text { meeting was held in } 2006\end{array}$ & Aim to start negotiations in 2006 \\
\hline Brunei & Agreed to start negotiations in 2006 & $\begin{array}{l}\text { Aim to start negotiations and agree on major points in } \\
2006\end{array}$ \\
\hline $\begin{array}{l}\text { Gulf Coast } \\
\text { Countries }^{1}\end{array}$ & Agreed to start negotiations in 2006 & Aim to start negotiations in 2006 \\
\hline India & $\begin{array}{l}\text { The first JSG meeting was held in } \\
2005\end{array}$ & $\begin{array}{l}\text { Decide whether or not to start negotiations based on } \\
\text { the JSG report scheduled to be submitted in } 2006\end{array}$ \\
\hline Switzerland & $\begin{array}{l}\text { The first JSG meeting was held in } \\
2005\end{array}$ & $\begin{array}{l}\text { Accelerate the work of joint study on which decision will } \\
\text { be made to start negotiations }\end{array}$ \\
\hline Australia & $\begin{array}{l}\text { The first JSG meeting was held in } \\
2005\end{array}$ & $\begin{array}{l}\text { Accelerate the work of joint study on which decision will } \\
\text { be made to start negotiations }\end{array}$ \\
\hline
\end{tabular}

1. The countries of the Gulf Co-operation Council (GCC). The GCC is comprised of Bahrain, Kuwait, Oman, Qatar, Saudi Arabia and the United Arab Emirates.

Source: Council on Economic and Fiscal Policy, Government of Japan, "Globalisation Strategy", May 2006.

\section{Improving the climate for FDI inflows in Japan}

3. FDI has become an increasingly important driver of global integration as multinational companies implement global strategies. During the second half of the 1990s, the worldwide total of FDI tripled (Figure 2), led by a marked rise in cross-border mergers and acquisitions (M\&As). Japan participated in this worldwide upswing, with its stock of inward FDI more than tripling from 3 trillion yen to 9.4 trillion yen between 1998 and 2002, thanks to a number of special factors. First, the failure of some major corporations and falling asset prices prompted restructuring, resulting in a number of large M\&As, particularly in the financial sector. Second, there was progress in regulatory reform, notably in the service sector and some of the network industries. Third, restrictions on FDI inflows have been relaxed since 1998, 
when Japan was ranked as the eighth-most restrictive OECD country (Golub, 2003), reflecting relatively slow progress in liberalising regulations during the preceding two decades. Its composite score in 1998 was 0.23 (with zero indicating no restrictions). ${ }^{3}$ By 2006, Japan's composite score had fallen to 0.15, encouraging FDI inflows even as the world total declined significantly after $2000 .{ }^{4}$ Consequently, Japan's share of world FDI inflows increased from $0.5 \%$ in 1998 to $1.2 \%$ in 2004.

Figure 2. Inward FDI in Japan and its share of the world total
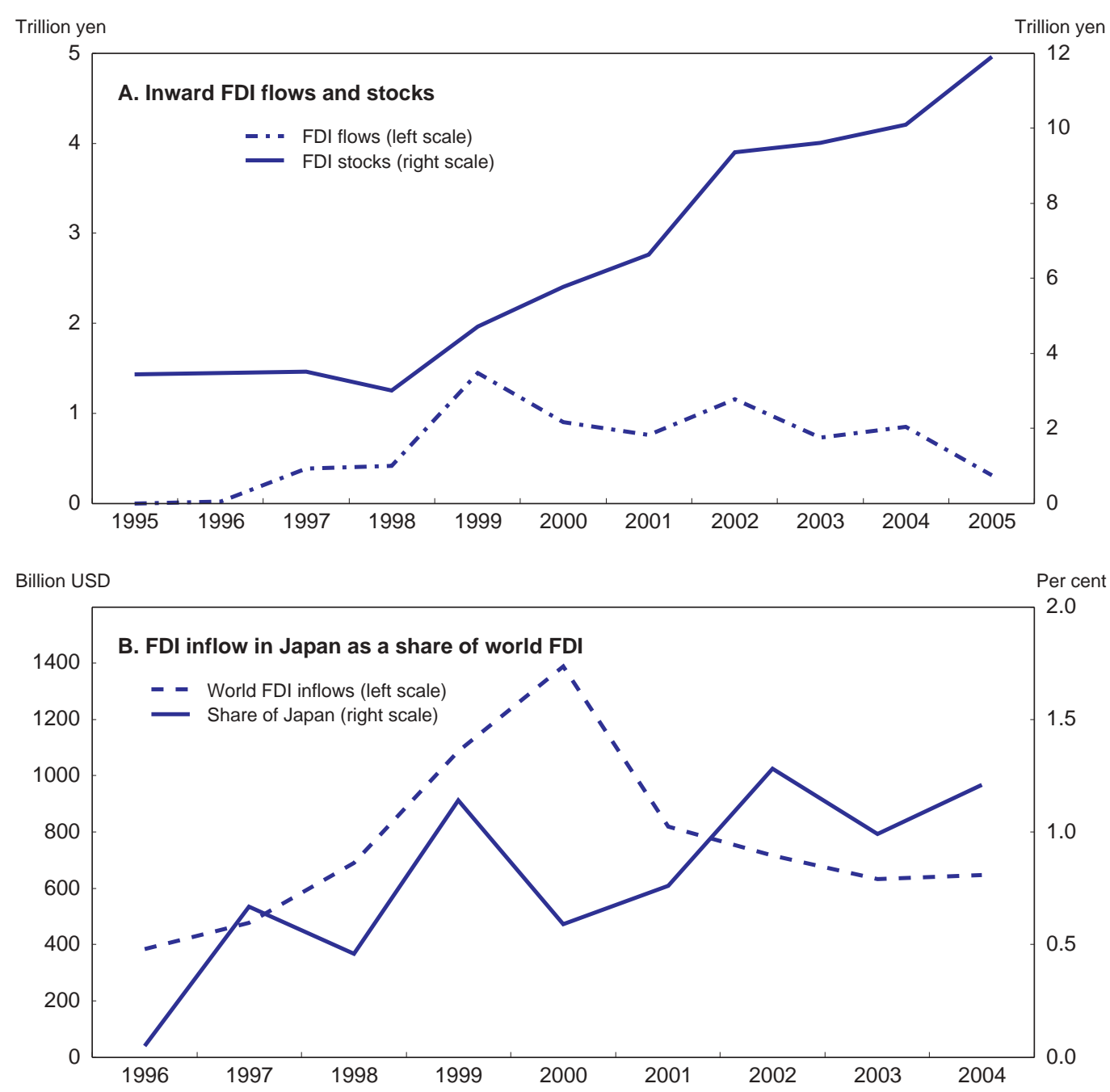

Source: Ministry of Finance, Japan External Trade Organization and UNCTAD (2005), World Investment Report 2005.

3. These restrictions have had a significantly negative impact on the stock of inward FDI in OECD countries, according to Nicoletti et al., 2003. Reducing FDI restrictions to the level of the least restrictive country (the United Kingdom) would have boosted the stock of inward FDI in the OECD area in the 1990s by $26 \%$.

4. The composite score is from an updating of Golub (2003). 


\section{$\mathrm{ECO} / \mathrm{WKP}(2006) 54$}

\section{Potential benefits from foreign direct investment inflows are large}

4. The surge in FDI inflows brought a number of benefits. In particular, labour productivity in foreign affiliates in Japan was $60 \%$ higher than the national average in the manufacturing sector and $80 \%$ higher in the service sector in 2002, a relatively large gap compared to other OECD countries (Figure 3). Moreover, foreign affiliates in the service sector in Japan recorded the highest labour productivity growth rate among OECD countries surveyed between 1995 and 2001 (OECD, 2005c). Another study found that the overall performance of foreign affiliates in Japan surpassed that of domestic companies in terms of total factor productivity (TFP), profitability, capital investment and spending on R\&D (Fukao, 2003). ${ }^{5}$ This reflects the fact that firms that undertake FDI are generally the most efficient in their industries.

Figure 3. Labour productivity of foreign affiliates relative to the national average In 2002, national average $=100$
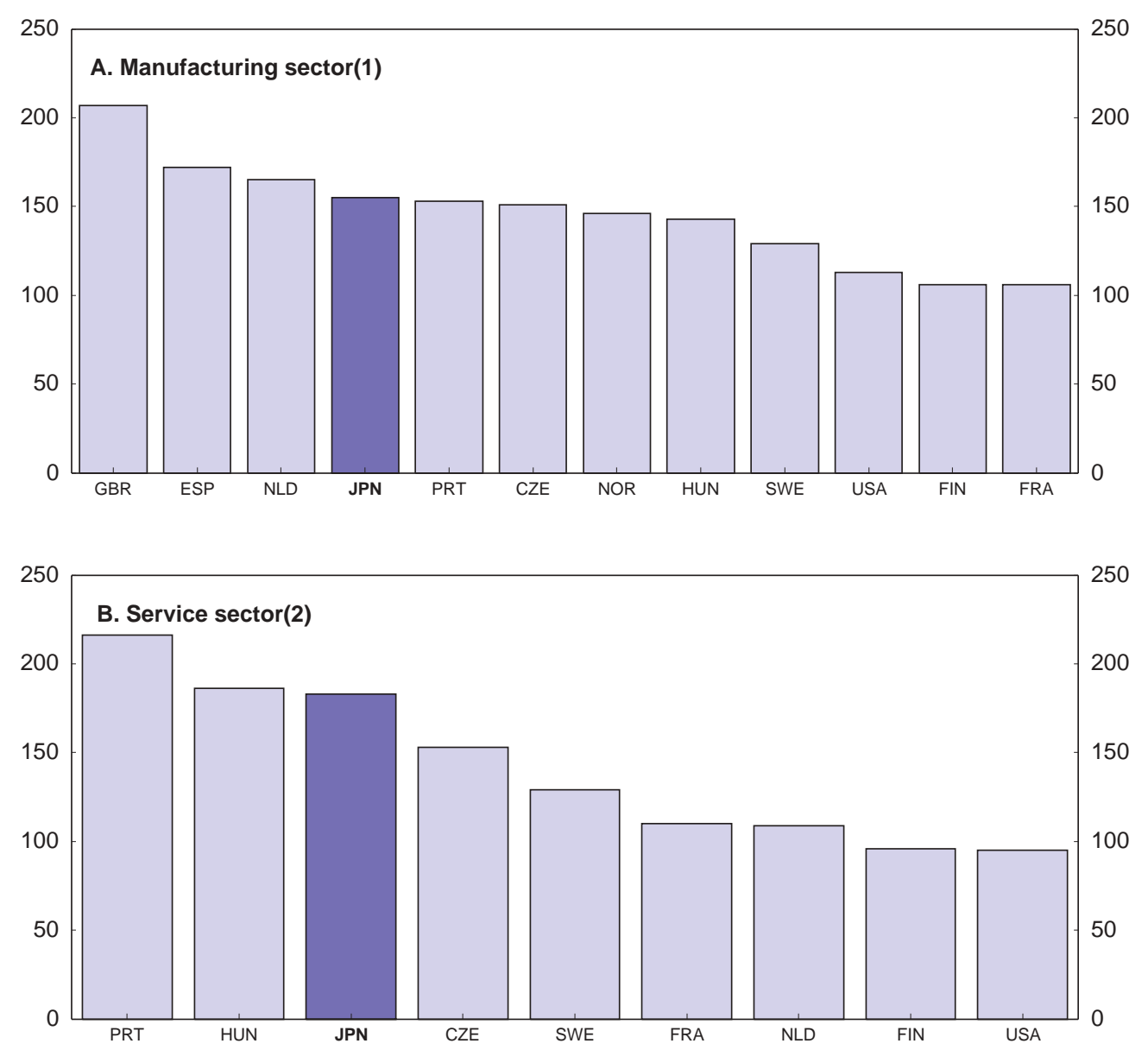

1. Manufacturing sector: 2000 for Spain; 1999 for the United Kingdom.

2. Service sector: 2001 for the Netherlands; 2000 for Sweden and Japan. Source: OECD (2005c), Economic Globalisation Indicators, 2005.

5. Compared to domestic firms, the level of TFP at foreign-owned firms is about $10 \%$ higher and the current profit-sales ratio is 2 percentage points higher. 
Figure 4. International comparison of inward foreign direct investment positions
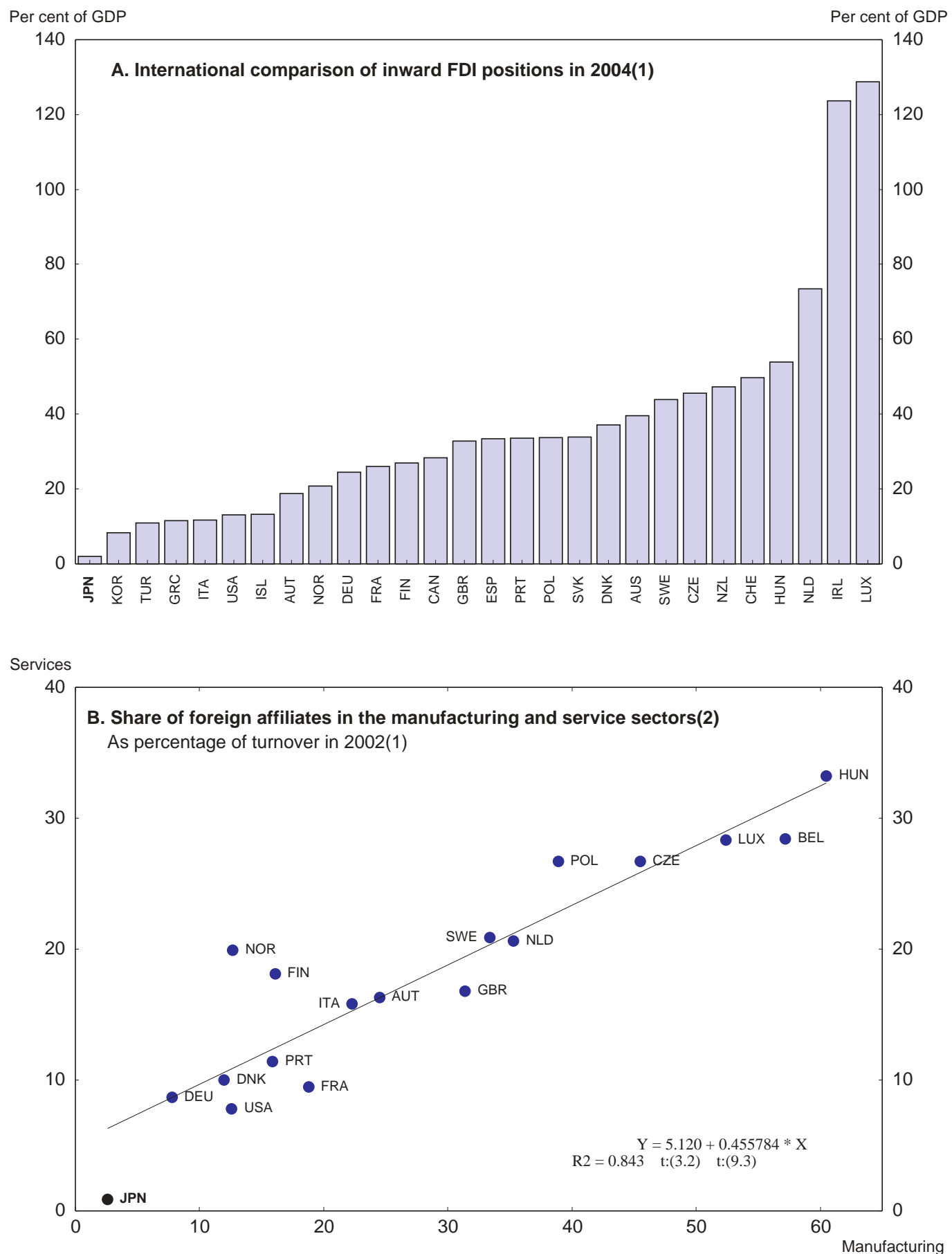

1. Or latest year. See the source for the exact year.

2. The data used for foreign affiliates are broken down by industry of sales to be compatible with national total data.

Source: OECD, International direct investment database and OECD (2005c), Economic Globalisation Indicators, 2005. 
5. However, the impact of foreign affiliates in Japan has been limited by their small size. Despite the three-fold increase between 1998 and 2002, the stock of FDI in Japan as a share of GDP remains the lowest in the OECD area at $\%$ (Figure 4). Consequently, the shares of foreign affiliates in manufacturing and service-sector turnover, at 1 and 3\% respectively, are also the lowest among OECD countries (Panel B). The share of FDI is particularly low in the service sector, which accounted for only $41 \%$ of the turnover of all foreign affiliates in Japan in 2002, the lowest in the OECD area. ${ }^{6}$ Foreign investment in services is essential to boost the relatively low level of productivity in that sector. Indeed, Japan's average labour productivity in services fell from 88\% of the US level in 1993 to $84 \%$ in 2003 despite a sharp rise in the finance, insurance, real estate and business service industries.

\section{It is essential to further reduce barriers to FDI inflows}

6. The special factors that drove the rapid inflow of FDI in the latter half of the 1990s are losing momentum. Despite government efforts in recent years to encourage inflows (Box 3), inward FDI fell to 0.3 trillion yen in 2005, the lowest figure since 1996 (Figure 2). The amount appears to be too low to have a significantly positive impact on the Japanese economy. Although the decline is due in part to the end of the global investment boom, the continued low share of Japan in world FDI suggests that there are still barriers to inflows. According to the OECD's FDI restrictiveness index, Japan is relatively open with an overall score that is well below the average of member countries (Koyama and Golub, 2006). ${ }^{7}$ However, this index is based primarily on discriminatory regulatory restrictions and hence does not capture all of the obstacles that a potential direct investor may face. These obstacles include: $i$ ) rules limiting cross-border M\&As; ii) product market regulations; and iii) labour market regulations. ${ }^{8}$

\section{Box 3. Recent initiatives to improve the FDI climate in Japan}

In 2003, Prime Minister Koizumi set a target of doubling the stock of inward FDI in Japan within 5 years from its 2001 level of 6.6 trillion yen. To meet this objective, the Japan Investment Council (JIC), which is chaired by the prime minister, established the "Programme for the Promotion of Foreign Direct Investment in Japan" that included 74 measures with the following goals: i) provide information on investment opportunities in Japan; ii) improve corporate governance and labor market practices; iii) create a favourable living environment in Japan; iv) review administrative procedures; and $v$ ) enlarge the role of local governments in attracting FDI. The programme was expanded to include 12 additional policy measures in July 2005, focusing on the following areas: i) improvement of the environment for cross-border M\&As; ii) regulatory reform of healthcare, and simplification of the application procedures for medicines, medical devices and food additives; and iii) strategic public relation strategies both inside and outside Japan.

The programme led to the creation in 2003 of the "Invest Japan Business Support Center", a one-stop office to provide information to foreign companies and potential foreign investors, located in the Japan External Trade Organization (JETRO). Information desks have also been established in all concerned ministries to help provide support for potential foreign investors navigating administrative procedures. In addition, the "Special Zones for Structural Reform" initiative launched in 2003 (see the 2005 OECD Economic Survey of Japan) has the potential to encourage foreign investment by relaxing regulations. In particular, the prohibition on corporations owning schools, hospitals and nursing homes has been waived and exemptions for visa requirements have been granted in some special zones. Finally, the "Advanced Areas to Promote Foreign Direct Investment" initiative launched in FY 2003 enables JETRO to provide special support to local governments that are trying to attract foreign capital. Five regions were selected in 2003.

6. See OECD, 2005c. The low proportion of services in Japan reflects the fact that almost all FDI regulations in the manufacturing sector, excluding the petroleum and leather industries, were lifted by 2003.

7. Japan had a score of 0.098 compared to an OECD average of 0.157 . These scores are not comparable to those in Golub, 2003.

8. A number of other factors, including a low expected rate of return, keiretsu and cross-shareholding, weak corporate governance and heavy reliance on internal finance, have been cited as factors limiting FDI inflows, but are beyond the scope of this chapter. In addition, negative public sentiment toward foreign investment may be another significant factor. Fukao (2003) argues that the historically restrictive policy stance toward foreign investment has created misunderstanding and negative public sentiment in Japan. 
Despite the slowdown in FDI inflows after 2002, the cumulative stock reached nearly 12 trillion yen in 2005 . With the 2006 target within reach, the CEFP announced in May 2006 a new target of doubling the stock of inward FDI to 5\% of GDP by 2010 (Box 2). With the OECD's second-largest economy and its location in the dynamic East Asian region, Japan has the potential to sharply increase its inflows of FDI. However, this is likely to depend on addressing the key issues discussed below rather than on action programmes and numerical targets. The political commitment at the top has to be matched by the ministries and agencies that implement the policies that influence actual inflows.

7. First, an open environment for FDI requires a competitive and non-discriminatory market for M\&As, which have emerged as a main driver of FDI by allowing multinational companies to bypass entry barriers and respond quickly to changes in business conditions. M\&As accounted for $59 \%$ of world FDI inflows in 2004 (UNCTAD, 2005). Between 1995 and 2001, there were 1404 major M\&A deals (valued at more than $\$ 100$ million) between the United States and Europe, with a total value of $\$ 1.4$ trillion (American Chamber of Commerce in Japan, 2005). Most of the deals were done on a "non-cash" basis in which the acquiring company paid for the target company through an exchange of shares, and taxes on the transaction were deferred. ${ }^{9}$ In contrast, there were only 138 major deals between Japan and the United States and Japan and Europe over the same period, with a total value of $\$ 116$ billion. During the period 2002 to 2004, the sale of EU companies to foreign firms accounted for almost half of the world total of cross-border M\&As in value terms, while the sale of US firms accounted for another one-fifth (Table 2). In contrast, the Japanese share was only $2.3 \%$.

8. Japan's low share of cross-border M\&As reflects several factors. One reason is that Japan's overall M\&A market is small based on international comparisons. ${ }^{10}$ Although the number has expanded five-fold from 531 in 1995 to 2725 in 2005, its size has been limited by the practice of cross-shareholding, combined with entrenched, internally promoted boards of directors who control the voting rights of such shares through informal shareholder understandings (Box 4). ${ }^{11} \mathrm{~A}$ second factor is the discriminatory treatment of foreign firms in M\&As. In particular, non-cash transactions are not allowed in the case of foreign firms, even though this method accounted for $70 \%$ of M\&As between domestic firms in 2002 (Fukao, 2003). Between 1999 and 2004, the share of cross-border M\&As in Japan's overall M\&A market fell from 11 to $9 \%$, while the amount of these deals declined from 2.5 trillion yen to 0.7 trillion yen (Table 2, Panel B).

9. The target company's shareholders are allowed to defer recognition of gains, thus delaying their tax liability until they dispose of the shares of the parent company.

10. Stock transactions as part of M\&As amounted to over $6 \%$ of market capitalisation in the United States and the European Union, compared to less than 2\% in Japan (Bank of Korea, 2005).

11. The top ten shareholders have a controlling position of $50 \%$ of shares in the majority of listed companies, with the largest shareholder having around $20 \%$. A successful M\&A, therefore, is usually not possible without their support. As a result, successful hostile bids in Japan are rare. 
Table 2. Cross-border mergers and acquisitions

A. World total by seller

\begin{tabular}{lrrrrrr}
\hline & \multicolumn{2}{c}{2002} & \multicolumn{2}{c}{2003} & 2004 \\
\cline { 2 - 7 } & \multicolumn{1}{c}{ Billions of US\$ } & Per cent & Billions of US\$ & Per cent & Billions of US\$ & Per cent \\
\cline { 2 - 7 } United States & 73.2 & 19.8 & 69.7 & 22.8 & 81.9 & 21.5 \\
European Union & 208.8 & 56.5 & 126.0 & 42.4 & 178.8 & 47.0 \\
Japan & 5.7 & 1.5 & 11.0 & 3.7 & 8.9 & 2.3 \\
Other OECD & 27.7 & 7.5 & 20.9 & 7.0 & 71.9 & 10.3 \\
Rest of World & 54.4 & 14.7 & 69.4 & 23.4 & 380.6 & 100.0 \\
Total & 369.8 & 100.0 & 297.0 & 100.0 & & \\
\hline
\end{tabular}

\section{B. In Japan (trillion yen)}

\begin{tabular}{lcc}
\hline & Cases & Amount $^{2}$ \\
\cline { 2 - 3 } $1988-91$ & 16 & - \\
$1992-96$ & 30 & - \\
1997 & 51 & 0.2 \\
1998 & 85 & 0.8 \\
1999 & 129 & 2.5 \\
2000 & 175 & 1.5 \\
2001 & 158 & 2.2 \\
2002 & 129 & 1.1 \\
2003 & 158 & 1.0 \\
2004 & 207 & 0.7 \\
\hline
\end{tabular}

1. Australia, Canada and New Zealand.

2. Based on public announcements.

Source: UNCTAD (2005) and Koo and Yang (2006).

9. Allowing foreign firms the same rights as domestic firms in using non-cash transactions for M\&As would significantly facilitate FDI inflows. The new Corporation Law enacted in June 2005 allows "triangular mergers". Under this law, a foreign company can establish a subsidiary in Japan, which then uses its parent company's stock to acquire a Japanese company. Although the revised provision was originally scheduled to take effect in May 2006, it has been delayed until May 2007 in the wake of concern about a hostile takeover attempt in early 2005 involving domestic companies. ${ }^{12}$ Moreover, there is concern over the proportion of shares owned by foreigners, which has risen from $10 \%$ in 1996 to $24 \%$ in 2005 . However, triangular mergers would do little to encourage hostile M\&As because, under Japanese law, it is required that mergers be approved by shareholders' vote on an extraordinary resolution, with a "super majority" of those present. Finally, the crucial question of whether to allow tax deferral for cross-border M\&As, as is generally the case at present for domestic M\&As involving the exchange of shares, is still under discussion within the government. Without the tax deferral, Japanese shareholders would be reluctant to agree to the share exchange with the parent foreign company.

12. These concerns have led to proposals for far-reaching "poison pills" to enable companies to frustrate any takeover bids. Such a reaction may be counterproductive with respect to other policy objectives. 
10. Second, product market regulations - defined as regulations that have the potential to reduce competitions in all sectors of the economy - have been found to impose significant barriers to FDI in OECD countries. Indeed, they have become more important as explicit restrictions have been gradually eliminated through successive rounds of multilateral trade negotiations, the rising number of regional trade agreements and investment accords. Given that potential foreign investors make decisions on the basis of expected returns, empirical studies show that countries with relatively restrictive and costly product market regulations tend to have lower stocks of foreign capital (Nicoletti et al., 2003). In the OECD's measure of "inward-oriented regulations", Japan is rated as the tenth most liberal along with Sweden, although it still has some room for improvement (Figure 5). The inward indicator includes two components: state control (Panel B), where Japan is one of the least restrictive, and barriers to entrepreneurship (Panel C), where it matches the OECD average. This suggests product market regulations are concentrated in various entry barriers that affect all potential investors, particularly in services (Fukao, 2003). Indeed, some markets, including network industries such as transport and electricity, as well as agriculture, healthcare and education are not open, either to foreign or domestic investors. ${ }^{13}$ Consequently, FDI in Japan's service sector is more concentrated in a limited number of industries (Ito and Fukao, 2003).

11. Third, labour market regulations also influence FDI flows. In particular, strict employment protection legislation has been found to reduce FDI inflows, in part by raising uncertainty about costs of restructuring (Nicoletti et al., 2003). Employment protection for regular workers in Japan is ranked as the tenth strictest in the OECD area (see the 2006 OECD Economic Survey of Japan).

12. The determinants of FDI and international trade are related, as indicated by the correlation between a country's stock of inward FDI and its exports and imports as a share of GDP. Foreign investment usually occurs after a firm achieves a market presence through trade. ${ }^{14}$ Once established, foreign affiliates tend to be more active in international trade, in part through intra-firm trade, than domestic firms (OECD, 2005c). Given the complementarity of trade and investment, easing barriers to trade should encourage FDI inflows. Similarly, liberalising barriers to FDI should promote trade.

13. The 2004 OECD Economic Survey of Japan examined regulatory issues that substantially limit competition and boost prices in air transport, harbours and road transport.

14. However, trade barriers may stimulate "tariff-jumping" FDI aimed at bypassing trade barriers. On balance, though, the removal of obstacles to trade has been found to boost FDI flows (Nicoletti et al., 2003). 


\section{Box 4. Cross-shareholding in Japan}

The ownership structure of firms has been characterised by a high level of cross-shareholding with financial institutions and other non-financial firms, such as business partners and the parent company. Indeed, until the mid-1990s, such shareholding accounted for nearly half of the value of listed companies, divided equally between banks, insurance firms and non-financial firms (Table 3). Stable cross-shareholding has been a key pillar of Japanese-style management and corporate governance. Banks' ownership of both debt and equity, it was argued, enhanced their ability to monitor client firms. However, a high level of bank ownership is associated with poor corporate performance as it reduces pressure from shareholders and the risk of hostile takeovers, thereby encouraging managerial entrenchment and raising the risk of insider control (Miyajima and Kuroki, 2005). Moreover, bank ownership of firms tends to relax financial constraints, allowing firms to undertake marginal investment projects with low rates of return.

Table 3. The proportion of stable shareholders in listed companies

The value of shares held by each sector as a per cent of the market value of firms

\begin{tabular}{c|c|ccc|c|}
\hline At the end of FY & $\begin{array}{c}\text { Number of listed } \\
\text { firms }\end{array}$ & Banks & Insurance firms & $\begin{array}{c}\text { Non-financial } \\
\text { firms }\end{array}$ & Total \\
\hline 1987 & 1924 & 14.9 & 16.4 & 14.4 & 45.8 \\
1988 & 1975 & 15.6 & 16.6 & 13.3 & 45.7 \\
1989 & 2031 & 15.6 & 15.7 & 13.4 & 44.9 \\
1990 & 2078 & 15.7 & 15.8 & 14.0 & 45.6 \\
1991 & 2107 & 15.6 & 16.2 & 13.7 & 45.7 \\
1992 & 2120 & 15.6 & 16.2 & 14.0 & 45.2 \\
1993 & 2161 & 15.4 & 15.8 & 13.7 & 44.9 \\
1994 & 2214 & 15.4 & 15.7 & 13.5 & 43.4 \\
1995 & 2279 & 15.0 & 14.7 & 11.6 & 42.1 \\
1996 & 2341 & 15.1 & 14.7 & 13.2 & 30.5 \\
1997 & 2389 & 14.8 & 14.1 & 15.9 & 39.9 \\
1999 & 2433 & 13.7 & 13.0 & 12.3 & 37.9 \\
2000 & 2487 & 11.3 & 10.6 & 1.4 & 33.0 \\
2001 & 2602 & 9.8 & 10.9 & 10.0 & 30.2 \\
\hline
\end{tabular}

Source: Miyajima and Kuroki (2005).

However, the share of stable shareholding has fallen significantly in recent years to around a quarter. The decline was particularly marked after 1997 when the banking crisis worsened, prompting banks to become large net sellers of shares in order to dispose of non-performing loans and to meet capital adequacy rules. In addition, a new law in 2001 required banks to reduce their equity holdings to no more than $100 \%$ of tier I capital in order to weaken the impact of stock market swings on the financial soundness of banks. This law has been a major impetus for sales of shares by banks, although the original deadline of September 2004 was pushed back to September 2006. Following the creation of the Banks' Shareholding Purchase Corporation in 2002, the Bank of Japan began to buy stocks directly from banks under certain conditions. Stable cross-shareholding was also reduced from the corporate side as profitable firms turned to direct financing from capital markets, thus reducing their interest in holding shares of the troubled banks.

The declining level of cross-shareholding should continue to facilitate a further development of the M\&A market in Japan, thus expanding the scope for cross-border deals that boost FDI inflows. However, the share of cross-border deals fell from a peak of 11\% of total M\&As in Japan in 1999 to 9\% in 2004 (Koo and Yang, 2006). Moreover, crossshareholding is likely to remain an important feature of the Japanese economy. 
Figure 5. Product market regulation in $2003^{(1)}$
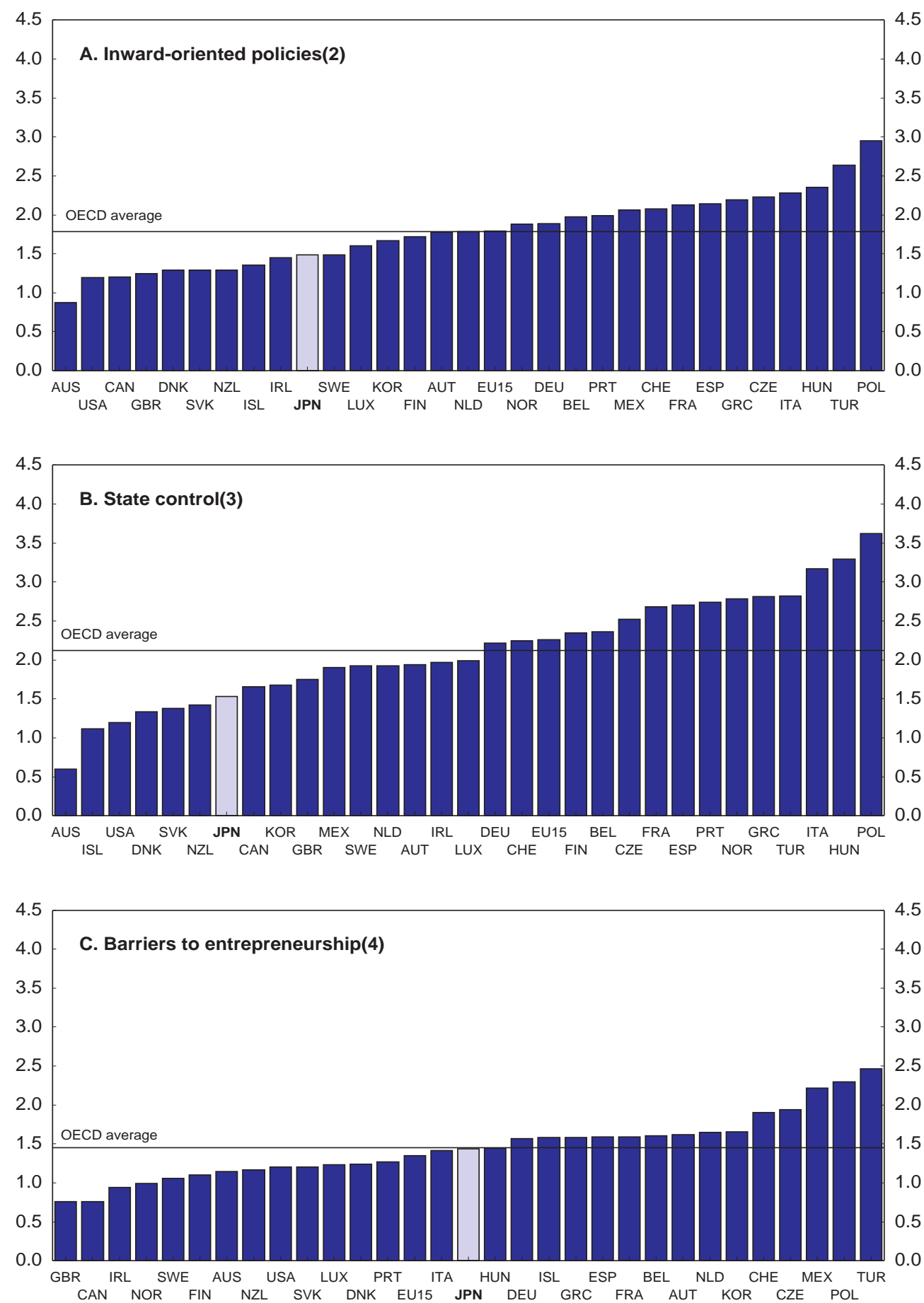

1. The scale of indicators is $0-6$ from least to most restrictive. OECD and EU15 are simple averages.

2. Excluding barriers to trade and investment.

3. State control covers public ownership of business enterprises and the government's involvement in business operations.

4. Barriers to entrepreneurship cover regulatory and administrative opacity, administrative burden on start-ups and barriers to competition, including entry barriers.

Source: Conway et al. (2005). 


\section{Accelerating international integration through trade}

13. The rapid increase in international trade in recent years is another important aspect of globalisation. Trade intensity (defined as the average of exports and imports divided by GDP) in the OECD area increased from an unweighted average of 35\% in 1995 to $47 \%$ in 2003 (OECD, 2005c). Meanwhile, Japan's trade intensity rose from 9 to $11 \%$ over the same period.

\section{Rising trade intensity in Japan: the China factor}

14. Over the past decade, imports of manufactured products increased from $8 \%$ of domestic demand to $13 \%$, with China accounting for three-fifths of the increase (Figure 6). Japan is now China's secondlargest export market, accounting for about $11 \%$ of total Chinese exports in 2004 . The rapid rise in trade has been driven in part by growing foreign investment, as Japanese firms take advantage of their geographical proximity to China's huge domestic market and lower labour costs. Indeed, the cost of labour in China on average is only about $5 \%$ of that in Japan. After decreasing in the second half of the 1990s, Japanese FDI in China jumped from $\$ 0.8$ billion in FY 1999 to $\$ 4.6$ billion in FY 2004. ${ }^{15}$ The expanding importance of China was accompanied by rising import shares for ASEAN and the Asian NIEs (Korea; Singapore; Chinese, Taipei; and Hong Kong, China). Consequently, Asia accounted for $85 \%$ of the increase in import penetration of manufactures in Japan over the past decade, despite the absence of formal agreements that have boosted trade in other regions, such as the North American Free Trade Agreement and the European Single Market initiative.

Figure 6. Import penetration in Japan

Imports of manufactures as a share of domestic demand

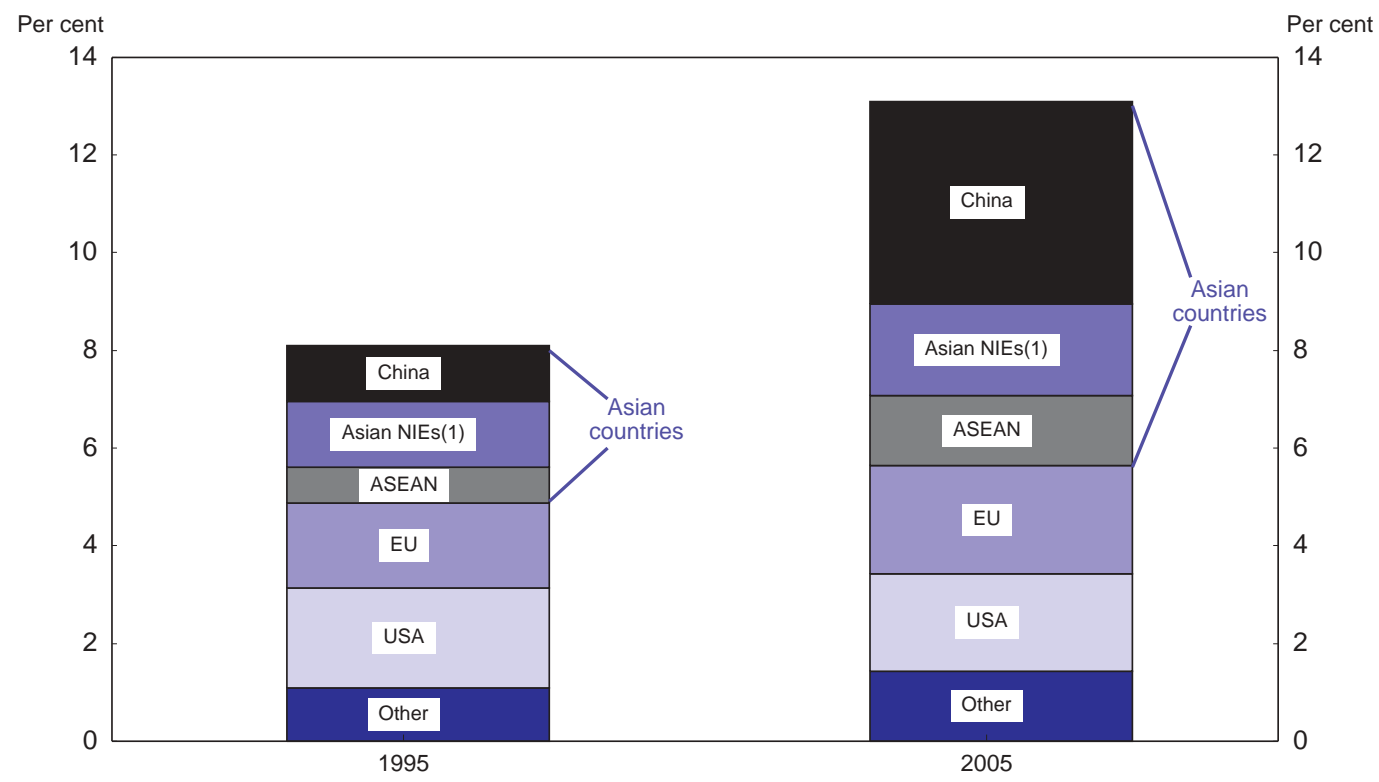

1. Hong Kong, China; Korea; Singapore; and Chinese, Taipei. Source : Japan External Trade Organisation.

15. Among OECD countries, Japan is the largest source of FDI in China, accounting for more than a quarter of the total stock of FDI in China from the OECD area. 
15. China has also accounted for Japan's rising export intensity in the manufacturing sector, which increased from $13 \%$ of domestic production in 1995 to $18 \%$ in 2003 . With Japanese exports to China growing at a $16 \%$ annual rate over the past decade, China has become the second largest market for Japanese exports, after the United States, with a share of $13 \%$ in 2005 . China has clearly played a key role in Japan's current economic expansion, which was driven primarily by external demand between 2002 and 2004. Growing trade with China has offset Japan's falling export market share in the OECD area. Indeed, Japan's share of intra-OECD imports of goods and services has fallen by $24 \%$ since 1995 , the largest decline in the OECD area. ${ }^{16}$ Increased exports to China limited the decline in Japan's share of world exports, which fell from 7.5 to $5 \%$ over the past decade. In sum, Japan has been the OECD country most affected by China's growing role in the world economy, which has accelerated the re-organisation of production in East Asia and the expansion of trade. There appears to be a clear division of labour between Japan and China, with little competition between the exports of the two countries, as Japan's exports tend to be higher value-added products (Kwan, 2002). Indeed, in 2002, only $16 \%$ of Chinese exports to the United States competed with Japanese products, while 38\% competed with Korean products, $49 \%$ with Malaysian products and $83 \%$ with Indonesian products.

\section{Japan's level of import penetration remains the lowest in the OECD area}

16. Despite Japan's growing investment and trade links with China and other Asian economies, the level of import penetration - defined as imports of goods as a share of domestic demand - remains the lowest in the OECD (Figure 7). The level of imports in Japan is surprisingly low, even after controlling for country size, transport costs and per capita income, although there may be other economic factors (Panel B). Explicit trade barriers are one possible explanation, although the simple average Most Favoured Nation tariff rate of 3.3\% in Japan is below the OECD average of 5.5\%. ${ }^{17}$ As for non-tariff barriers, these applied to $5.6 \%$ of total imports, a level of coverage similar to other major OECD countries according to UNCTAD (Bora et al., 2002). However, the restrictive effect of tariff and non-tariff barriers, according to research done at the World Bank (Kee et al., 2006), is relatively high. The combined effect of tariffs and non-tariff measures is given by the Overall Trade Restrictiveness Index, which shows the tariff level that keeps imports at their observed level (second column of Table 4). According to this broad estimate, the level of trade protection is $14.3 \%$ in Japan, compared to $12.6 \%$ in the European Union and $8.2 \%$ in the United States. In addition to formal trade barriers, the low import penetration appears to result from other factors, including product market regulation and the low stock of FDI in Japan. Moreover, the upward trend in Japan's import penetration ratio has been slowed by the country's small number of regional trade agreements. These factors are discussed below.

16. Japan's share of OECD exports to the United States declined sharply from $24 \%$ in 1995 to $14 \%$ in 2003 while it remained at around 33\% in China and Hong Kong, China (OECD, 2005c).

17. According to the World Trade Organisation, the simple average applied tariff rate (including ad valorem equivalents of non-ad valorem duties) was $6.3 \%$ in 2004 in Japan, compared to $4.9 \%$ in the United States and $6.5 \%$ in the European Union. This is due to the higher rate for agriculture - at $17.7 \%$ - in Japan. 


\section{$\mathrm{ECO} / \mathrm{WKP}(2006) 54$}

Figure 7. Indicators of openness in trade

A. Import penetration rates for goods as per cent of domestic demand
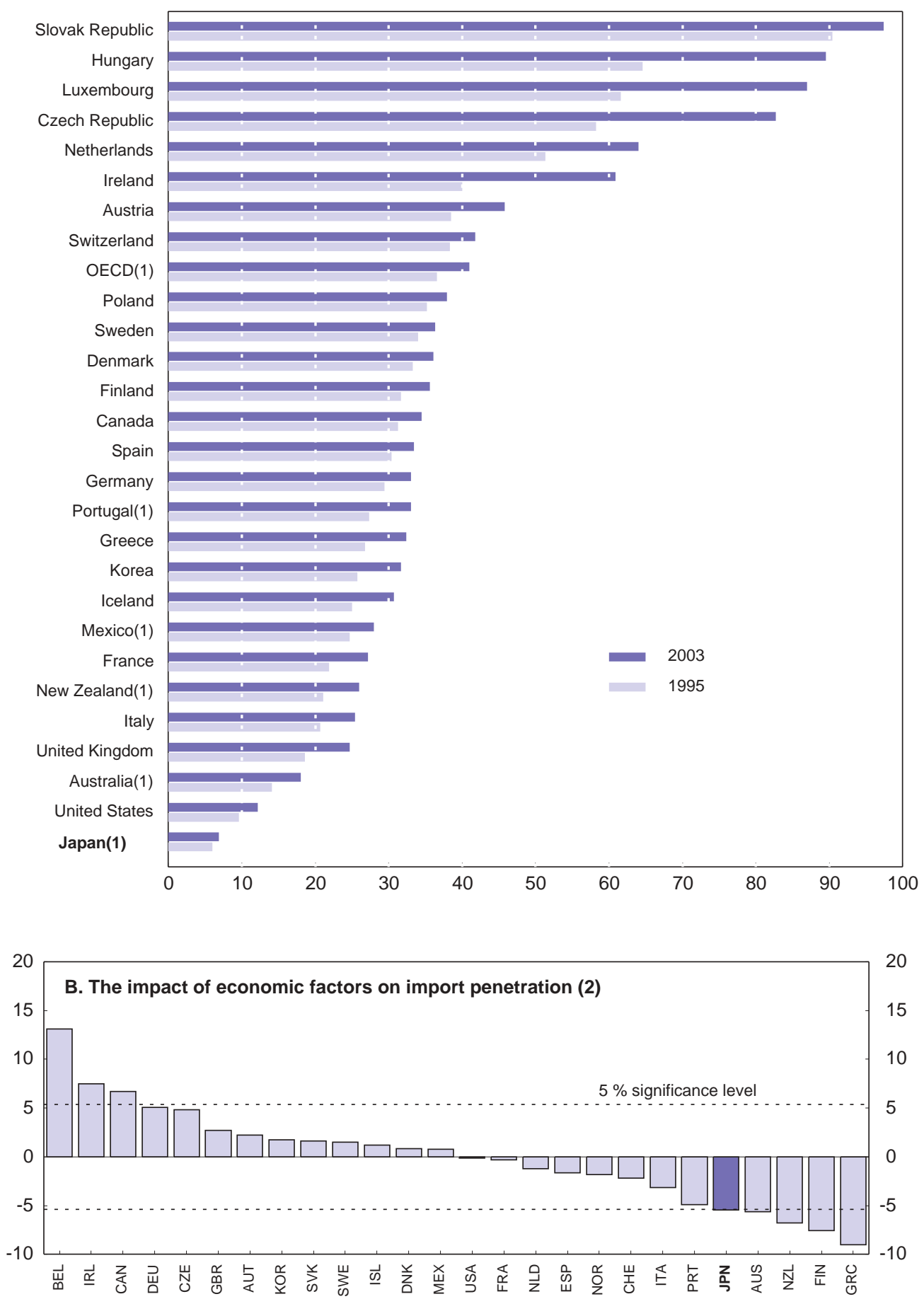

1. Data for Australia, Japan, Mexico, New Zealand and Portugal refer to 2002.

2. Import penetration (the 1995-2004 average for goods and services) is estimated as a function of population, per capita income and transport costs. A negative (positive) residual indicates that import penetration is below (above) the level predicted by economic factors. For Japan and four other countries, these residuals are significant at a $5 \%$ level.

Source: OECD (2005c), OECD Economic Globalisation Indicators 2005 and National Accounts. 
Table 4. Trade barriers in OECD countries ${ }^{1}$

\begin{tabular}{lcc}
\hline \multicolumn{1}{c}{ Country } & OTRI using tariffs & $\begin{array}{c}\text { OTRI using } \\
\text { tariff and } \text { non- } \\
\text { tariff barriers }\end{array}$ \\
\hline Australia & 4.7 & 11.6 \\
Canada & 3.1 & 6.1 \\
Switzerland & 5.7 & 5.4 \\
Czech republic & 4.0 & 5.0 \\
European Union & 3.0 & 12.6 \\
Hungary & 6.1 & 11.3 \\
Iceland & 3.2 & 5.6 \\
Japan & $\mathbf{5 . 8}$ & 14.3 \\
Mexico & 14.8 & 28.7 \\
Norway & 4.6 & 7.5 \\
New Zealand & 2.4 & 12.7 \\
Poland & 10.8 & 15.2 \\
Turkey & 7.1 & 11.8 \\
United States & 2.7 & 8.2 \\
OECD (13 countries above) & $\mathbf{5 . 8}$ & $\mathbf{1 1 . 0}$ \\
\hline
\end{tabular}

1. Overall trade restrictive index (OTRI) is the uniform tariff that would leave aggregate imports unchanged. It is defined as the weighted sum of tariff and non-tariff barriers. Non-tariff-barriers include price control measures, quantity restrictions, monopolistic measures and technical regulations.

Source: Kee et al (2006), "Estimating trade restrictiveness indices", Centre for Economic Policy Research Discussion Paper No. 5576, London.

17. Restrictive product market regulations reduce imports, in part by making market access more difficult and by distorting relative prices and rates of return (Nicoletti et al., 2003). While the impact is larger for services, it also influences trade in manufactures. As noted above, although Japan ranks as the tenth most liberal country in inward-oriented regulations, it has some room for improvement (Figure 5).

18. The small role of foreign affiliates in Japan appears to be another factor contributing to low import penetration. Indeed, there is a strong correlation between the stock of FDI and imports of manufactures, given that foreign affiliates play a key role in the globalisation process, in part through intrafirm trade. ${ }^{18}$ As noted above, the share of foreign affiliates in Japan's manufacturing and service sectors is the lowest in the OECD in terms of turnover (Figure 4, Panel B). Correspondingly, they played only a minor role in Japan's international trade, accounting for $7 \%$ of total exports and $9 \%$ of total imports in 2001. In France, for example, the corresponding ratios are 29\% and 39\% (OECD, 2005c).

19. Finally, a factor limiting the rise in import penetration is that Japan has not participated in the worldwide surge in regional trade agreements (RTAs) - which include bilateral trade agreements - during the past 15 years. Indeed, the number of such agreements increased from 27 in 1990 to 188 in 2005 (Figure 8). Japan is a relatively recent participant, with no such agreements prior to 2002 . This may have had negative implications for FDI as well as trade. In Canada and Australia, 64\% and 34\% respectively of inward FDI is covered by a RTA or a Bilateral Investment Treaty (BIT), compared to only $4 \%$ in Japan (OECD, 2005c). Meanwhile, 12\% of Japan's outward investment is thus covered, well below the $47 \%$ for Australia and $44 \%$ in Canada.

18. In Japan, the share of intra-firm trade in imports of foreign affiliates was $72.3 \%$ in $2001(\mathrm{OECD}, 2005 \mathrm{c})$. 
Figure 8. The number of regional trade agreements

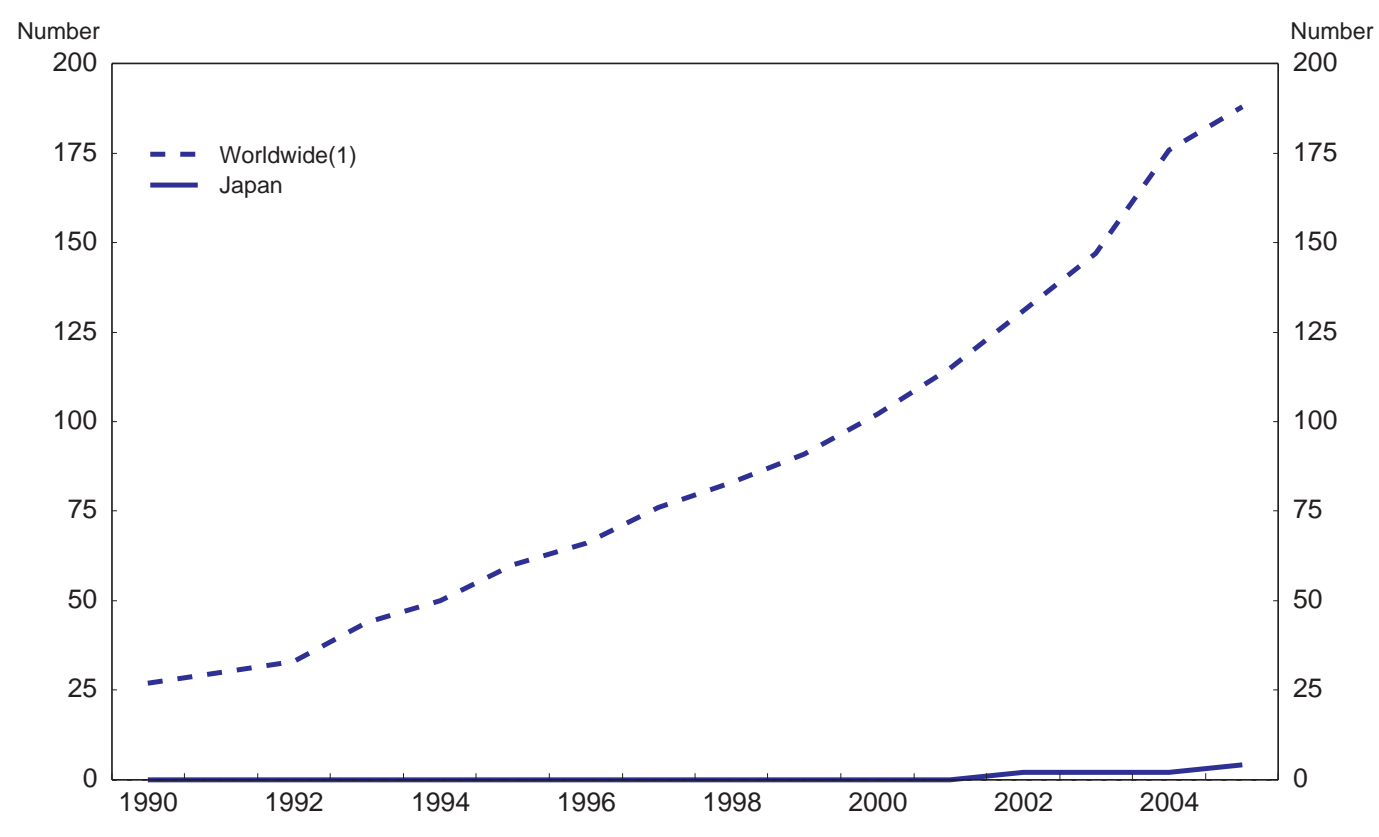

1. The number of agreements in force that have been notified to the GATT/WTO. Source: World Trade Organisation.

\section{Promoting trade liberalisation}

20. Expanding trade through multilateral trade negotiations and regional trade agreements thus appears to be essential. Japan's trade policy has traditionally given priority to the multilateral approach, which is indeed the optimal approach to reducing trade barriers. It is only in recent years that Japan has pursued regional trade arrangements as a second track. Although there is debate as to whether regional agreements are building blocks or stumbling blocks to multilateral liberalisation, the World Trade Organisation allows such agreements as long as they cover substantially all trade. Currently, Japan has bilateral agreements - which it calls Economic Partnership Agreements (EPAs) ${ }^{19}$ - with Singapore, Malaysia and Mexico (Table 5). In addition, Japan plans to sign agreements with Thailand and the Philippines as early as possible. ${ }^{20}$ Meanwhile, negotiations are under way with Indonesia, ASEAN as a whole, Chile and Brunei. Japan also agreed to launch negotiations with India and the GCC (Gulf Cooperation Council) in 2006. Finally, Japan has had joint study group meetings with Vietnam to examine the possibility of launching negotiations and also with Australia and Switzerland to explore ways to strengthen economic relations. However, the negotiations with Korea that began in 2003 have been suspended.

19. The name reflects the fact that the agreements go beyond the removal of tariff and non-tariff barriers to include the liberalisation of FDI and flows of human resources and economic and technical cooperation.

20. Japan aims to sign the agreement with the Philippines as early as possible in 2006 and the agreement with Thailand as soon as the political situation in Thailand will allow. 
Table 5. Overview of Japan's regional trade agreements and expected economic impact ${ }^{1}$

\begin{tabular}{|c|c|c|c|c|c|c|c|}
\hline \multirow[t]{2}{*}{ Country } & \multicolumn{2}{|c|}{$\begin{array}{l}\text { Share of Japan's } \\
\text { exports in } 2005\end{array}$} & \multicolumn{2}{|c|}{$\begin{array}{l}\text { Share of Japan's } \\
\text { imports in } 2005\end{array}$} & \multirow[t]{2}{*}{ Status } & \multirow{2}{*}{$\begin{array}{l}\text { Impact on } \\
\text { real GDP }\end{array}$} & \multirow{2}{*}{$\begin{array}{l}\text { Impact on } \\
\text { agricultural } \\
\text { production }\end{array}$} \\
\hline & Ranking & $\begin{array}{c}\text { Share } \\
(\%)\end{array}$ & Ranking & $\begin{array}{c}\text { Share } \\
(\%)\end{array}$ & & & \\
\hline Singapore & $8^{\text {th }}$ & 3.1 & $20^{\text {th }}$ & 1.3 & $\begin{array}{l}\text { Signed and took effect } \\
\text { in } 2002 \text {. Negotiations } \\
\text { for a partial revision of } \\
\text { this EPA were agreed } \\
\text { in } 2006 \text {. }\end{array}$ & 0.00 & -0.03 \\
\hline Mexico & $19^{\text {th }}$ & 1.2 & $30^{\text {th }}$ & 0.5 & $\begin{array}{l}\text { Signed in } 2004 \text { and } \\
\text { took effect in } 2005\end{array}$ & 0.06 & -0.13 \\
\hline Malaysia & $11^{\text {th }}$ & 2.1 & $11^{\text {th }}$ & 2.9 & $\begin{array}{l}\text { Signed in } 2005 \text { and } \\
\text { expected to take effect } \\
\text { in } 2006\end{array}$ & 0.06 & -0.04 \\
\hline Philippines & $14^{\text {th }}$ & 1.5 & $16^{\text {th }}$ & 1.5 & $\begin{array}{l}\text { Agreed on major points } \\
\text { in } 2004\end{array}$ & 0.01 & -0.03 \\
\hline Thailand & $6^{\text {th }}$ & 3.8 & $10^{\text {th }}$ & 3.0 & $\begin{array}{l}\text { Agreed on major points } \\
\text { in } 2005 \text { and expected } \\
\text { to be signed in } 2006\end{array}$ & 0.14 & -0.32 \\
\hline Indonesia & $13^{\text {th }}$ & 1.6 & $7^{\text {th }}$ & 4.0 & $\begin{array}{l}\text { Started negotiations in } \\
2005\end{array}$ & 0.03 & -0.02 \\
\hline Australia & $12^{\text {th }}$ & 2.1 & $5^{\text {th }}$ & 4.7 & $\begin{array}{l}\text { The first Joint Study } \\
\text { Group (JSG) meeting } \\
\text { was held in } 2005\end{array}$ & 0.15 & -1.71 \\
\hline ASEAN $^{2}$ & $3^{\text {rd }}$ & 12.7 & $2^{\text {nd }}$ & 14.0 & $\begin{array}{l}\text { Started negotiations in } \\
2005\end{array}$ & - & - \\
\hline Chile & $48^{\text {th }}$ & 0.2 & $23^{\text {rd }}$ & 1.0 & $\begin{array}{l}\text { The first JSG meeting } \\
\text { was held in } 2005 \text { and } \\
\text { four meetings have } \\
\text { been held thus far }\end{array}$ & 0.00 & -0.03 \\
\hline Switzerland & $31^{\text {st }}$ & 0.4 & $24^{\text {th }}$ & 1.0 & $\begin{array}{l}\text { The first JSG meeting } \\
\text { was held in } 2005\end{array}$ & 0.00 & 0.00 \\
\hline India & $26^{\text {th }}$ & 0.6 & $28^{\text {th }}$ & 0.6 & $\begin{array}{l}\text { The first JSG meeting } \\
\text { was held in } 2005\end{array}$ & 0.06 & -0.06 \\
\hline Korea & $3^{\text {rd }}$ & 7.8 & $6^{\text {th }}$ & 4.7 & $\begin{array}{l}\text { Started negotiations in } \\
2003 \text { but stopped since } \\
2004\end{array}$ & 0.10 & -0.02 \\
\hline China & $2^{\text {nd }}$ & 13.4 & $1^{\text {st }}$ & 21.0 & - & 0.50 & -0.86 \\
\hline European Union ${ }^{2}$ & $2^{\text {nd }}$ & 14.4 & $3^{\text {rd }}$ & 11.2 & - & 0.20 & -0.73 \\
\hline USA & $1^{\text {st }}$ & 22.6 & $2^{\text {nd }}$ & 12.4 & - & 0.24 & -3.72 \\
\hline Canada & $15^{\text {th }}$ & 1.5 & $14^{\text {th }}$ & 1.7 & - & 0.08 & -1.38 \\
\hline New Zealand & $29^{\text {th }}$ & 0.4 & $31^{\text {st }}$ & 0.5 & - & 0.01 & -0.07 \\
\hline
\end{tabular}

1. Economic impact of regional trade agreements is based on estimates of the static gains using a computable general equilibrium model of global trade (Kawasaki, 2005).

2. Ranking is based on the combined share of member countries: The European Union is based on 25 countries. Source: Ministry of Foreign Affairs, Japan External Trade Organization and Kawasaki (2005a). 
21. These trade agreements are likely to increase income in Japan through the usual static and dynamic gains that result from increased international trade (Box 1), assuming that the impact of "trade creation" exceeds that of "trade diversion". Using a computable general equilibrium model of global trade, Kawasaki's study (2005a) estimates the static gains. The result of this study suggests that the static gains from each of the five agreements that are in effect or already agreed are positive but extremely small at around $0.1 \%$ of GDP (Table 5). The result also suggests that the impact from potential EPAs with Australia, China, the United States and the European Union is likely to be much larger, reflecting the trade structure, market size and income level of these potential counterparts. However, there are currently no plans for bilateral agreements with the United States, the European Union or China, ${ }^{21}$ while progress with Australia is limited to a joint study for enhancing economic relations. Kawasaki's study estimates that EPAs with major trading partners would likely be accompanied by reductions of 1 to $4 \%$ in Japan's agricultural production. Currently, out of five countries holding joint study meetings with Japan, three are relatively important in Japan's agricultural imports - Australia (8.2\%), Chile (2.8\%) and Vietnam (1.8\%) while the other two account for a relatively small share in Japan's agricultural imports - India (1.0\%), Switzerland $(0.1 \%){ }^{22}$

22. In addition to hindering the negotiation of EPAs with some key trading partners, the high level of protection accorded to agriculture is preventing Japan from reaping larger benefits from regional trade agreements. In the case of Mexico, Japan increased the proportion of total imports that are duty-free from 70 to $87 \%$, but the tariff liberalisation ratio ${ }^{23}$ was less than $50 \%$ for agricultural products. The impact is likely to be smaller than other countries such as Thailand and the Philippines, as Mexico supplies less than $1 \%$ of Japan's agricultural imports. ${ }^{24}$ In the case of Thailand and Malaysia, sensitive products, such as rice and pork, are excluded from liberalisation. The exclusion of "sensitive areas" appears to be an obstacle to WTO consistent regional trade agreements. This limits exports of industrial products where Japan has a competitive advantage.

23. The high level of agricultural protection thus limits the scope for income gains from trade agreements, while imposing heavy burdens on consumers. Although agricultural support, as measured by the Producer Support Estimate, has fallen from $64 \%$ of the value of agricultural production in 1986-88 to $58 \%$ in 2003-05, it is still almost double the OECD average (Figure 9). Such protection more than doubled farm income (Panel B). The Japanese government estimates that the monetary cost borne by consumers, which is defined as the difference between domestic and foreign prices of agri-food commodities, amounted to as much as $2.1 \%$ of GDP in 2000 (Cabinet Office, 2004).

21. Discussions with China will likely occur in the context of ASEAN+3 (Japan, China and Korea). An EPA that includes the ASEAN+3 countries is estimated to increase consumer welfare in Japan by $0.3 \%$ of GDP (Scollay and Gibert, 2001).

22. The data on import shares are found in the Trade Data Base of the Japan External Trade Organization.

23. The tariff liberalisation ratio is defined as the value of Mexico's agricultural products exempt from import tariffs as a percentage of Mexico's total agricultural exports to Japan. In addition, to the abolition of tariffs, there were additional market access improvements for both manufactured and agricultural products through tariff rate reductions and tariff rate quota expansions.

24. See Ahearn (2005). In Japan's other EPA now in effect - that with Singapore - agriculture is largely irrelevant. Thailand and the Philippines account for $4.8 \%$ and $1.8 \%$, respectively, of Japan's agricultural imports. 
Figure 9. International comparison of agricultural support

A. Trends in the producer support estimate(1)

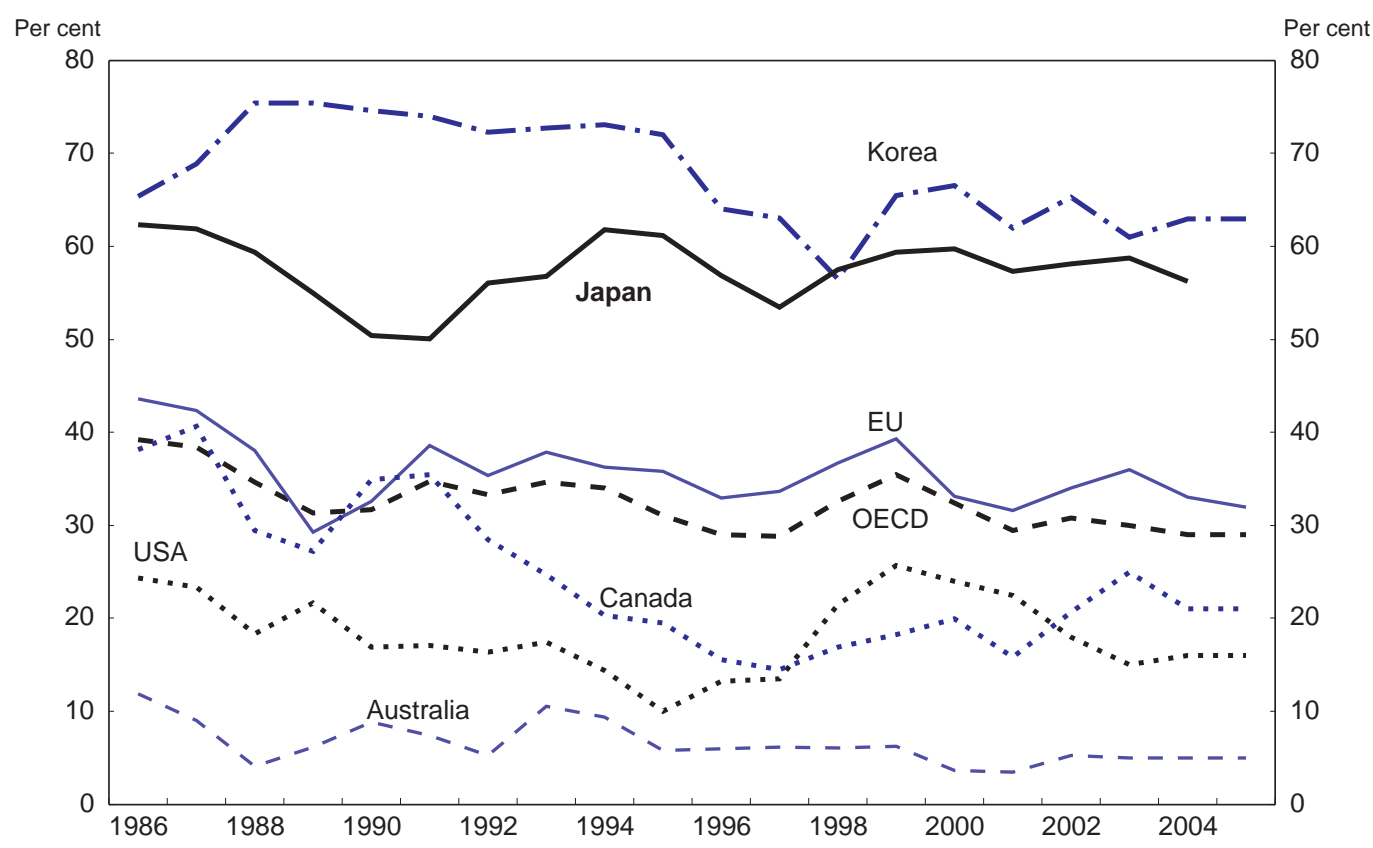

B. Trends in the nominal protection coefficient(2)

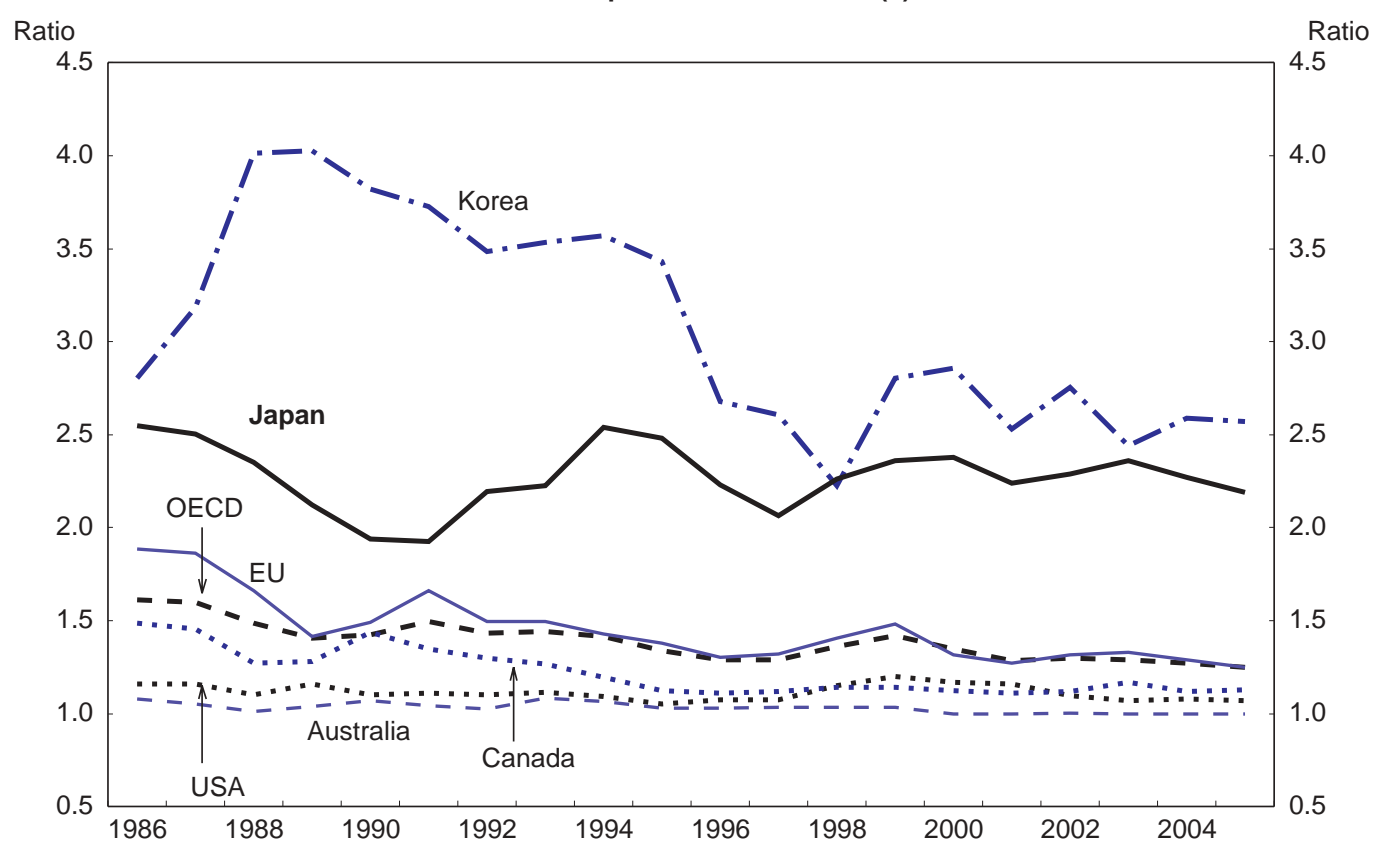

1. The PSE is an indicator of the value of monetary transfers to agriculture resulting from agricultural policies. It is presented as a share of the total value of production at domestic producer prices.

2. The NPC is a measure of market protection defined as the ratio between the average prices received by producers and border prices.

Source: OECD (2006), OECD Agricultural Policies 2006: At A Glance. 
24. A more market-oriented agricultural policy in Japan is a key to promoting the success of multilateral trade negotiations and the creation of regional trade agreements. This requires shifting farm policies away from targeting output of individual commodities through price policy and border measures. Such market price supports, which account for $91 \%$ of the support provided to farmers, measured on a Producer Support Estimate (PSE) basis, distort trade and production decisions. Beginning in 2006, the government is shifting towards a multi-commodity system in which support will be concentrated on larger, more efficient farms. Such an approach should aim at replacing market price supports with direct support for farmers, thus limiting distortions in trade and production, and encouraging the consolidation of farms. The average farm size, currently about 1.6 hectares, limits productivity gains. The recent decision to allow companies to rent and manage agricultural land should help boost efficiency. Finally, the goal set in the 2005 Basic Plan for Food, Agriculture and Rural Areas to raise self-sufficiency in food from 40 to $45 \%$ by 2015 may raise the concern that this goal will be accomplished through protectionism. Such concerns could be reduced if policies focus primarily on reducing costs to consumers by eliminating distortions to trade and production decisions.

\section{Liberalising the inflow of workers to Japan}

25. Increasing the number of foreign workers is a major issue in regional trade agreements, given that some Asian countries wish to see improved opportunities for their nationals to work in Japan as part of such agreements. Labour mobility was included in the agreement with Singapore, although its coverage was very limited. ${ }^{25}$ This topic was a difficult issue in negotiations with Thailand and the Philippines, which wanted their nationals to be allowed to work in Japan, notably as nurses and care-givers for the elderly. In principle, Japan agreed to allow Philippine nurses and care-givers to work in Japan, provided that they pass qualification exams in Japanese. However, the number and selection process for allowing such workers have not been determined and it remains to be seen if the qualification criteria will act as an entry barrier (Ahearn, 2005).

26. In addition to hindering the creation of regional trade agreements, restrictions on foreign labour may also discourage inflows of FDI. One of the difficulties that foreign firms face in doing business in Japan is securing internationally qualified employees, particularly in the areas of legal services, engineering, biotechnology, financial accounting and IT ${ }^{26}$ Domestic business groups also see a need for more foreign workers who are specialists in technical fields and in areas where there are labour shortages (Keidanren, 2005). However, there are others who argue that careful consideration is necessary before substantially increasing immigration. For example, the Ministry of Health, Labour and Welfare expressed concerns during the formulation of the Globalisation Strategy that expanding the inflow of manual workers would have a negative impact on the domestic labour market, social security expenditures, the educational level and public safety.

27. During the post-war era, Japan has had very small inflows and outflows of population, leaving net migration at close to zero, in contrast to significant inflows to the United States and the European Union (Figure 10). The low number of inflows reflects the fact that employment is officially limited to

25. Only short-term visitors for commercial purposes, intra-firm transferees, investors, and engineers with high technological knowledge are included, and then only temporary stays are permitted.

26. According to the European Business Council in Japan (2005), "One of the greatest difficulties European firms continue to face doing business in Japan is securing internationally qualified Japanese employees for their Japanese operations. Unfortunately, Japan's education and certification system does not effectively address the widening gap between competency levels and the needs of employers in today's increasingly global economy, especially for skills in areas such as legal services, engineering, biotechnology, financial accounting, and IT. Moreover, the market for mid-career professionals is still underdeveloped, which inhibits the expansion of European businesses in Japan." 
foreign workers who are allowed to stay one to three years in Japan. ${ }^{27}$ Foreign residents with work permits totalled 180 thousand in 2002 (Table 6), accounting for only $0.3 \%$ of the labour force in 2002, the lowest in the OECD area and well below the average of 9\%. Moreover, nearly one-third of that total consists of the not very well-defined category of "entertainers". If other types of foreign workers are included - the descendants of Japanese emigrants who have returned to Japan, illegal workers, foreign students with parttime jobs and trainees, the total foreign labour force is substantially larger at around 760 thousand in 2002, but is still only $1.1 \%$ of the labour force.

Figure 10. Net migration in major OECD areas Thousand persons(1)

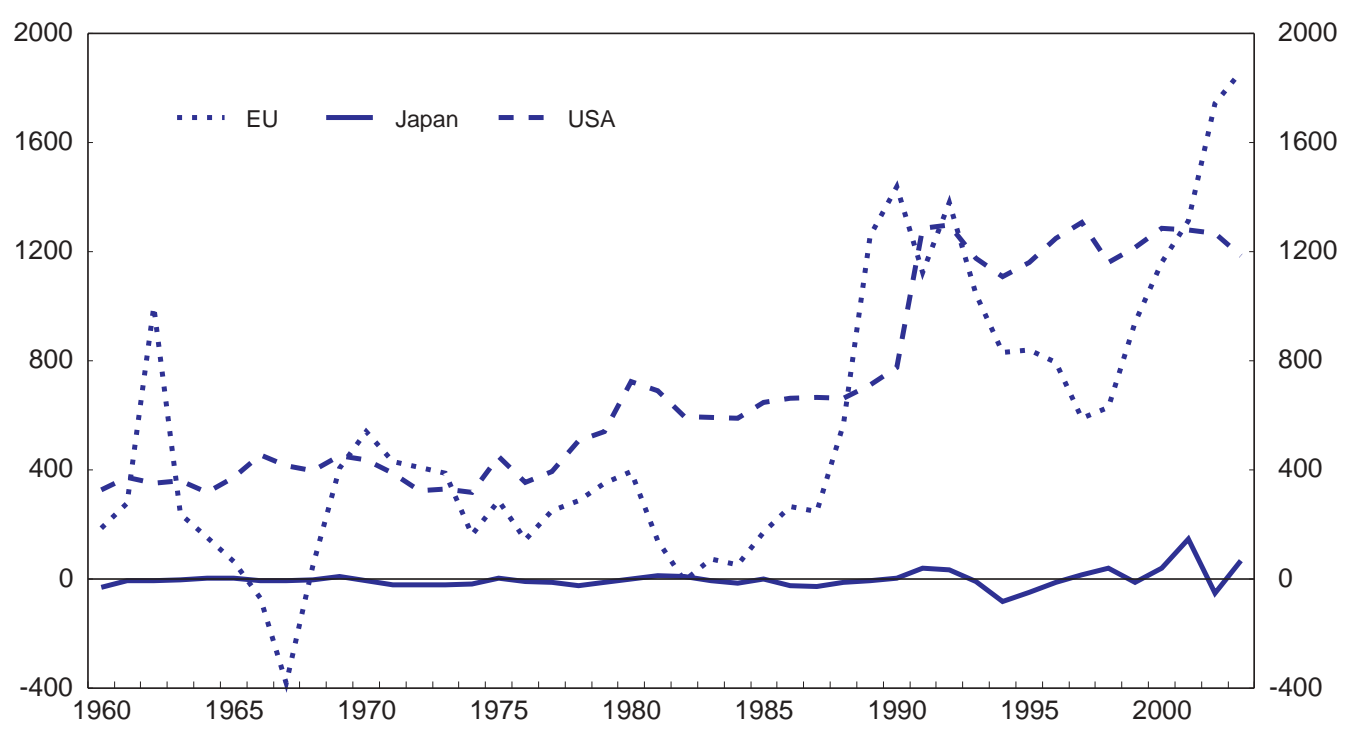

1. Net migration is measured as the difference between the total population on 1 January and 31 December for a given calendar year, minus the difference between births and deaths. Source: OECD, Labour Force Statistics.

28. Liberalising the inflow of foreign labour will have positive effects both on productivity, by attracting highly skilled workers to Japan, and on labour inputs. Regarding the latter, it is important to meet labour shortages, particularly for long-term nursing care, where demand is growing rapidly due to population ageing. This requires expanding the occupational areas open to foreign workers to include fields, such as nursing care, which are classified as non-technical. Another aspect of increasing foreign labour is greater recognition of foreign qualifications and diplomas. Although larger inflows will help attenuate the impact of a falling working-age population, it is not capable of fully offsetting demographic changes.

29. Instead, policies to encourage female labour force participation are more important in terms of limiting the decline in the labour force. Female labour force participation is currently close to the OECD average but well below the level in the other major countries apart from Italy. If female participation rates were boosted to the current level for men by the year 2030, the decline in the total labour force would be limited to 4\% over the next 25 years (see the 2005 OECD Economic Survey of Japan). However, if female participation rates remain at their current level, the labour force would fall by nearly a fifth, significantly boosting the burden of population ageing. A number of policy initiatives recommended in the previous

27. Foreign wokers are allowed to renew their period of stay if they satisfy certain requirements. 
Survey to encourage female labour force participation remain important: $i$ ) Reducing dualism in the labour market would help expand regular employment - at a significantly higher salary - enhancing the attractiveness of employment for women; ii) The tax and social security systems should be reformed to reduce disincentives to work by spouses, in particular by lowering or removing the thresholds at which the income of second earners is exempted; iii) Increasing the importance of performance assessment in pay and promotion decisions would reduce the importance of seniority and tenure, thus tending to narrow wage gaps between genders; $i v$ ) The use of age limits in recruiting should be discouraged; and $v$ ) The availability of childcare facilities should be increased by easing the licensing regulations and encouraging more private-sector firms to enter this sector.

Table 6. The foreign population in Japan Thousands

\begin{tabular}{|c|c|c|c|}
\hline & 1999 & 2002 & Per cent ${ }^{1}$ \\
\hline \multicolumn{4}{|l|}{ A. Total foreign population } \\
\hline Inflows of foreign nationals ${ }^{2}$ & 281.9 & 343.8 & 0.3 \\
\hline Stock of foreign nationals, by status of residence & 1556.1 & 1851.8 & 1.5 \\
\hline Permanent residents ${ }^{3}$ & 635.7 & 713.8 & 0.6 \\
\hline Long-term residents ${ }^{4}$ & 492.5 & 522.7 & 0.4 \\
\hline Foreign workers with permission of employment & 125.7 & 179.6 & 0.1 \\
\hline Other (accompanying, student, trainee etc.) & 302.1 & 435.6 & 0.4 \\
\hline Naturalisations & 16.1 & 14.3 & 0.0 \\
\hline \multicolumn{4}{|l|}{ B. Labour force } \\
\hline 1. Foreign residents with permission of employment, by visa category: & 125.7 & 179.6 & 0.3 \\
\hline Entertainer & 32.3 & 58.4 & \\
\hline Specialist in humanities or international services & 31.8 & 44.5 & \\
\hline Engineer & 15.7 & 20.7 & \\
\hline Skilled labour & 10.5 & 12.5 & \\
\hline Intra-company transferee & 7.4 & 10.9 & \\
\hline Instructor & 8.1 & 9.7 & \\
\hline Professor & 5.9 & 7.8 & \\
\hline Investor and business manager & 5.4 & 6.0 & \\
\hline Religious activities & 5.0 & 4.9 & \\
\hline Researcher & 2.9 & 3.4 & \\
\hline Journalist & 0.4 & 0.4 & \\
\hline Artist & 0.4 & 0.4 & \\
\hline Medical services & 0.1 & 0.1 & \\
\hline Legal and accounting services & 0.1 & 0.1 & \\
\hline Total & 125.7 & 179.6 & \\
\hline 2. Trainees & 23.3 & 46.4 & 0.1 \\
\hline 3. Estimates of foreign students engaged in part-time jobs & 47.0 & 83.3 & 0.1 \\
\hline 4. Estimates of Japanese descendents engaged in gainful activities ${ }^{4}$ & 220.5 & 233.9 & 0.3 \\
\hline 5. Illegal workers ${ }^{5}$ & 251.7 & 220.6 & 0.3 \\
\hline 6. Total foreign labour force ${ }^{6}$ & 670.0 & 760.0 & 1.1 \\
\hline Number of foreign nationals deported & 55.2 & 41.9 & \\
\hline
\end{tabular}

1. Of total population in 2002 for Panel A. Of total labour force in 2002 for Panel B.

2. Excluding temporary visitors (i.e. less than 90 days) and re-entries.

3. Essentially Korean nationals. There are no restrictions on their employment.

4. Primarily the descendents of Japanese who emigrated to South America. There are no restrictions on their employment.

5. Estimates made by the Ministry of Justice on the basis of the number of persons who overstayed their visa.

6. Excluding permanent residents.

Source: OECD (2005f), Trends in International Migration. 
30. Expanding the availability of childcare facilities may also help boost the rate of fertility, which has fallen from 2.1 children per women in 1970 to 1.3 in 2000, one of the lowest in the OECD area. The government's objective is to increase the fertility rate while boosting female employment. The positive correlation between fertility and female employment among OECD countries suggests that it is possible to accomplish both objectives (Figure 11). Indeed, a cross-country analysis found that expanding the availability of childcare and lengthening parental leaves somewhat can increase the fertility rate (D'Addio and Mira d'Ercole, 2005), while at the same time encouraging women to work (Jaumotte, 2003). There is scope to expand childcare in Japan, as only $33 \%$ of the children between three and the age of mandatory schooling were attending formal childcare, compared to the OECD average of $73 \%$. Other policies that reduce the direct cost of children, such as child benefits, also boost fertility rates in OECD countries. However, such policies have also been found to lower female employment by reducing the need to work (Jaumotte, 2003). Given the importance of mitigating population ageing through greater female labour force participation, policy measures to increase fertility should focus on those likely to also boost female employment. While higher fertility may have many advantages in the long run, it would do little to ease the impact of population ageing during the next 25 years.

Figure 11. Female employment rates and total fertility rates 2000

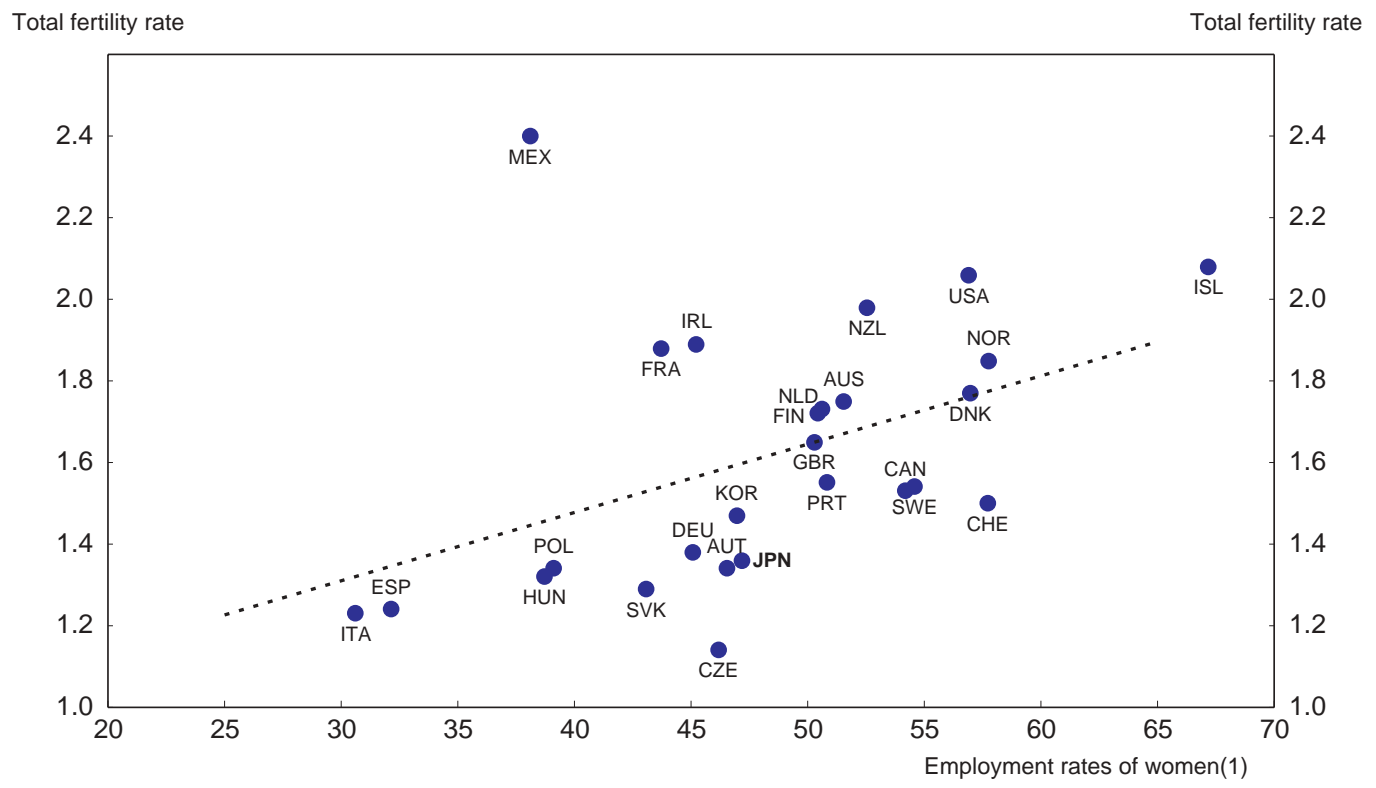

1. Refers to women aged $15-64$.

Source: D'Addio and Mira d'Ercole (2005).

\section{Conclusion}

31. Despite improvements in recent years, Japan's import penetration, FDI inflows and immigration of labour remain low compared to other OECD countries. Reducing direct and indirect barriers to strengthened integration with the world economy would increase productivity and living standards and help Japan to cope with population ageing. Specific recommendations are shown in Box 5. It is important to address policies related to international trade, FDI and labour flows in a comprehensive manner as they are closely linked together. Hence, policies that succeed in expanding one channel of globalisation would have a positive effect on the others. For example, a more open policy on foreign workers would also facilitate the creation of more complete economic partnership agreements that promote trade, and thus FDI inflows. Similarly, resolving the cross-border M\&A issue would increase FDI inflows and hence trade. 
32. The government's effort to increase FDI inflows is a positive signal, although the rationale for numerical targets is less clear. The key to expanding the role of foreign affiliates in Japan is to provide a business-friendly environment and ensure transparency, equal treatment and free competition based on market principles. Inflows of FDI would be likely to increase in such an environment, though that should not be the only objective of such reforms, which would also benefit domestic firms. Pursuing reforms that enhance Japan's integration in the global economy will thus boost productivity in the domestic economy as well, thereby helping to sustain the rise in living standards.

\section{Box 5. Summary of recommendations to strengthen integration in the world economy}

FDI, international trade and flows of labour are closely linked. In particular, improving the climate for FDI inflows depends on measures to boost import penetration. At the same time, a better climate for FDI encourages international trade. Other specific policies to enhance globalisation in Japan are listed below.

\section{Improving the climate for inflows of foreign direct investment}

- Use the FDI doubling objective as a spur to create a more open and transparent climate for FDI and as a guide in decisions by ministries and agencies that have implications for potential foreign investors.

- $\quad$ Fully open the M\&A market to foreign firms by allowing them to use their own shares to finance mergers and granting them the same tax deferrals that are available in the case of domestic M\&As.

- $\quad$ Further lift specific restrictions on FDI, especially in the service sector and network industries.

- Accelerate regulatory reform in product markets, such as removing entry barriers for both foreign and domestic firms, notably in medical care, education, transport, electricity and professional services.

- Relax employment protection for regular workers, which tends to also help encourage foreign investment.

\section{Removing obstacles to international trade}

- $\quad$ Pursue the liberalisation of trade barriers, giving priority to multilateral trade negotiations, complemented by regional trade agreements, to further reduce the level of trade restrictions, including tariff and non-tariff barriers.

- $\quad$ Strengthen market pressures in the agricultural sector, in part by reducing market price supports, thereby promoting trade liberalisation in a multilateral context and broadening the scope for regional trade agreements.

- Allow greater flexibility in the inflow of human resources, including both specialists and non-specialists, which would also facilitate comprehensive regional trade agreements with major trading partners.

- $\quad$ Pursue further regulatory reform in product markets in part to improve access for imports.

\section{Encouraging the inflow of human resources to Japan}

- Improve the immigration control system to allow more highly qualified persons to work in Japan.

- Expand the range of qualifications that permit foreign personnel to work in Japan and increase recognition of qualifications and diplomas acquired overseas.

- Increase the number of occupational categories where foreigners are allowed to work to include nonspecialised and non-technical professions, such as providing long-term care for the elderly. 
ECO/WKP(2006)54

\section{Bibliography}

Ahearn, Raymond (2005), "Japan's Free Trade Agreement Program", CRS Report for Congress, Washington D.C.

American Chamber of Commerce in Japan (2003), FDI policy in Japan: From goals to reality, Tokyo.

American Chamber of Commerce in Japan (2004), Tax-Deferred Share Exchanges Using Foreign Company Shares, Tokyo.

Bank of Korea (2005), "The recent debate over hostile M\&A in Japan”, Overseas economy bulletin, Seoul.

Bora, Bijit, Aki Kuwahara and Sam Laird (2002), "Quantification of Non-tariff Measures”, United Nations Conference on Trade and Development (UNCTAD) Study Series No. 18, New York and Geneva.

Cabinet Office (2004), Economic and Public Finance White Paper 2004, Tokyo.

Conway, Paul, Veronique Janod and Giuseppe Nicoletti (2005), "Product Market Regulation in OECD Countries: 1998 to 2003”, OECD Economics Department Working Papers No. 419, Paris.

Coppel, Jonathan, Jean-Christophe Dumont and Ignazio Visco (2001), "Trends in Immigration and Economic Consequences", OECD Economic Department Working Papers No. 284, Paris.

D'Addio, Anna and Marco Mira d'Ercole (2005), "Trends and Determinants of Fertility Rates in OECD Countries: The Role of Policies", OECD Social, Employment and Migration Working Papers No. 27.

European Business Council in Japan (2004), Trade, Investment and the Reform Nexus, Tokyo.

Ferrantino, Michael (2005), "Quantifying Trade and Economic Effects of Non-Tariff Measures", OECD Trade Policy Working Papers No. 28, Paris.

Fukao, Kyoji and Tomofumi Amano (2003), "Foreign direct investment and the Japanese economy", American Chamber of Commerce, Tokyo.

Fukao, Kyoji and Yukako Murakami (2004), "Do Foreign Firms Bring Greater Total Factor Productivity to Japan?", Research Institute for Industry, Economy and Trade (RIETI) Discussion Paper Series 04-E-014, RIETI, Tokyo.

Fukao, Kyoji, Keito Ito and Hyeog Ug Kwon (2004), "Characteristics and Effects of Japan's Inward FDI", Tokyo.

Gaulier, Guillaume, Françoise Lemoine and Deniz Unal-kesenci (2004), "China's Integration in Asian Production Networks and its Implications", Research Institute for Industry, Economy and Trade (RIETI) Discussion Paper Series 04-E-033, RIETI, Tokyo.

Golub, Steve (2003), "Measures of Restrictions on Inward Foreign Direct Investment for OECD Countries”, OECD Economic Studies, No. 36, Paris.

Hoj, Jens and Michael Wise (2004), "Product Market Competition and Economic Performance in Japan", OECD Economics Department Working Papers No. 387, Paris. 
Ito, Keiko and Kyoji Fukao (2001), "Foreign Direct Investment in Japan, Empirical Analysis Based on Establishment and Enterprise Census", Research Institute for Industry, Economy and Trade (RIETI) Discussion Paper Series 01-E-002, RIETI, Tokyo.

Ito, Keiko and Kyoji Fukao (2003), "Foreign Direct Investment and Trade in Japan, An Empirical Analysis Based on Establishment and Enterprise Census for 1996", Discussion Paper Series A No. 441, The Institute of Economic Research, Hitotsubashi University, Tokyo.

Japan Bank for International Cooperation (2002), "Foreign Direct Investment and Development: Where Do We Stand?" Japan Bank for International Cooperation (JBIC) Research Papers No.15, JBIC, Tokyo.

Japan External Trade Organization (2005), Japanese Trade in 2004, Tokyo.

Kawasaki, Kennichi (2003a), "The Impact of Free Trade Agreements in Asia", Research Institute for Industry, Economy and Trade (RIETI), Discussion Paper Series 03-E-18, Tokyo.

Kawasaki, Kennichi (2005b), "The Economic Impacts of FTAs", Presented at the ESRI International Workshop on FTAs, Tokyo.

Kawasaki, Kennichi (2005), “The Sectoral and Regional Implications of Trade Liberalization”, Submitted to the $8^{\text {th }}$ Annual Conference on Global Economic Analysis, Center for Global Trade Analysis, Purdue Univeristy, West Lafayette, Indiana.

Kee, H.L., A. Nicita and M. Olarrega (2006), "Estimating Trade Restrictiveness Indices", Centre for Economic Policy Research Discussion Papers No. 5576, London.

Keidanren (2005), Keidanren Priority Policies 2004-05, Tokyo.

Kiyota, Kozo and Shujiro Urata (2005), "The role of Multinational Firms in International Trade: The Case of Japan", Research Institute for Industry, Economy and Trade (RIETI) Discussion Paper Series 05E-012, RIETI, Tokyo.

Kongsrud, Per Mathis and Isabelle Wanner (2005), "The impact of Structural Polices on Trade-related Adjustment and the Shift to Services”, OECD Economics Department Working Papers No. 427.

Koo, Bonkwan and Junho Yang (2006), M\&A strategy by foreign firms", Samsung Economic Research Institute Issue Paper, Seoul (in Korean).

Koyama, Takeshi and Steve Golub (2006), “OECD's FDI Regulatory Restrictiveness Index: Update and Extension to More Economies", OECD Economics Department Working Paper, forthcoming.

Kwan C. H. (2002), "The Rise of China and Asia's Flying-Geese Pattern of Economic Development: An Empirical Analysis Based on US Import Statistics", Research Institute for Industry, Economy and Trade (RIETI) Discussion Paper Series 02-E-009, RIETI, Tokyo.

Ministry of Economy, Trade and Industry of Japan (2002), "The Agreement between Japan and the Republic of Singapore for a New-Age Economic Partnership", Tokyo.

Ministry of Foreign Affairs of Japan (2001), Diplomatic Bluebook 2001, Tokyo. 
Miyajima, Hideaki and Fumiaki Kuroki (2005), "The Unwinding of Cross-shareholding: Causes, Effects, and Implications", in Corporate Governance in Japan: Institutional Change and Organizational Diversity, edit by M. Aoki, G. Jackson and H. Miyajima.

Munakata, Naoko (2001), "Evolution of Japan's policy toward Economic Integration”, Research Institute for Industry, Economy and Trade (RIETI) Discussion Paper Series 02-E-006, RIETI, Tokyo.

Munakata, Naoko (2002), “Whither East Asian Economic Integration?” Research Institute for Industry, Economy and Trade (RIETI) Discussion Paper Series 02-E-007, RIETI, Tokyo.

Nicoletti, Giuseppe, Steve Golub and Dana Hajkova (2003), "The Influence of Policies on Foreign Direct Investment”, Experts' meeting on FDI in developing Asia, Asia Development Bank \& OECD Development Centre, Paris.

Nicoletti, Giuseppe, Steve Golub, Dana Hajkova, Daniel Mirza and Kwang-Yeol Yoo (2003), "Policies and International Integration: Influences on Trade and Foreign Direct Investment", OECD Economics Department Working Papers No. 359, Paris.

Nicoletti, Giuseppe, Steve Golub, Dana Hajkova, Daniel Mirza and Kwang-Yeol Yoo (2003), "The Influence of Policies on Trade and Foreign Direct Investment", OECD Economic Studies, No. 36.

OECD (2002), Foreign Direct Investment for Development, Paris.

OECD (2004a), Japan: Progress in Implementing Regulatory Reform, OECD Reviews of Regulatory Reform, Paris.

OECD (2004b), OECD Economic Survey of Japan, Paris.

OECD (2005a), "The benefits of liberalising product markets and reducing barriers to international trade and investment in the OECD”, OECD Economics Department Working Papers No. 463, Paris.

OECD (2005b), International investment Perspectives, Paris.

OECD (2005c), OECD Economic Globalisation Indicators, Paris.

OECD (2005d), OECD Economic Survey of Japan, Paris.

OECD (2005e), Trade and Structural Adjustment, Paris.

OECD (2005f), Trends in International Migration, Paris.

OECD (2006), OECD Economic Survey of Japan, Paris.

UNCTAD (2005), World Investment Report, New York and Geneva.

World Trade Organization (2004), Trade Policy Review: Japan, Geneva.

Yusuf, Shahid and Kaoru Nabeshima (2005), “Japan's Changing Industrial Landscape”, World Bank Policy Research Working Paper 3758, Washington D.C. 
$\mathrm{ECO} / \mathrm{WKP}(2006) 54$

\section{WORKING PAPERS}

The full series of Economics Department Working Papers can be consulted at www.oecd.org/eco/Working_Papers/

525. OECD's FDI regulatory restrictiveness index: Revision and extension to more economies (November 2006) Sven Blöndal and Alain de Serres

524. Globalisation and inflation in the OECD economies

(November 2006) Nigel Pain, Isabell Koske and Marte Sollie

523. Identifying determinants of Germany's international price competitiveness - A structural VAR approach (November 2006) Martin Meurers

522. Short-term pain for long-term gain: the impact of structural reform on fiscal outcomes in EMU (November 2006) Paul van den Noord and Boris Cournède

521. Interactions between monetary and fiscal policy: How monetary conditions affect fiscal consolidation (November 2006) Rudiger Ahrend, Pietro Catte and Robert Price

520. Restoring fiscal sustainability in the Euro Area: raise taxes or curb spending? (October 2006) Boris Cournède and Frédéric Gonand

519. Should Measures of Fiscal Stance be Adjusted for Terms of Trade Effects (October 2006) David Turner

518. Monetary policy and inflation expectations in Latin America: Long-run effects and volatility spillovers (October 2006) Luiz de Mello and Diego Moccero

517. Social safety nets and structural adjustment

(September 2006) Paul van den Noord, Nathalie Girouard and Christophe André

516. Adapting the Icelandic education system to a changing environment (September 2006) Hannes Suppanz

515. Forecasting monthly GDP for Canada (September 2006) Annabelle Mourougane

514. Finland's housing market: reducing risks and improving policies (September 2006) Laura Vartia

513. The Danish housing market: Less subsidy and more flexibility (September 2006) Espen Erlandsen, Jens Lundsgaard and Felix Huefner

512. Labour market reform in Germany: How to improve effectiveness (September 2006) Eckhard Wurzel

511. Removing obstacles to employment for women in Ireland (September 2006) Boris Cournède

510. Assessing Russia's non-fuel trade elasticities: Does the Russian economy react "normally" to exchange rate movements?

(September 2006) Christian Gianella and Corinne Chanteloup

509. Regulation, competition and productivity convergence

(September 2006) Paul Conway, Donato De Rosa, Giuseppe Nicoletti and Faye Steiner 
508. Improving education achievement and attainment in Luxembourg to compete in the labour market (September 2006) David Carey and Ekkehard Ernst

507. Raising economic performance by fostering product market competition in Germany (August 2006) Andrés Fuentes, Eckhard Wurzel and Andreas Reindl

506. Regulation of financial systems and economic growth (August 2006) Alain de Serres, Shuji Kobayakawa, Torsten Sløk and Laura Vartia

505. Enhancing Portugal's human capital (August 2006) Bénédicte Larre and Stéphanie Guichard

504. Improving labour market performance in France Améliorer la performance du marché du travail en France (July 2006) Stéphanie Jamet

503. Wage setting in Finland: Increasing flexibility in centralised wage agreements (July 2006) Åsa Johansson

502. Taxation, business environment and FDI location in OECD countries (July 2006) Dana Hajkova, Giuseppe Nicoletti, Laura Vartia and Kwang-Yeol Yoo

501. The political economy of structural reform: Empirical evidence from OECD countries (July 2006) Jens Høj, Vincenzo Galasso, Giuseppe Nicoletti and Thai-Thanh Dang

500. Labour market performance, income inequality and poverty in OECD countries (July 2006) Jean-Marc Burniaux, Flavio Padrini and Nicola Brandt

499. Improving Public-Spending Efficiency in Czech Regions and Municipalities (July 2006) Philip Hemmings

498. Policies to Promote Innovation in the Czech Republic (July 2006) Alessandro Goglio

497. Getting Education Right for Long-Term Growth in the Czech Republic (July 2006) Alessandro Goglio

496. Assessing the 2005 Czech Proposals for Pension Reform (July 2006) Philip Hemmings and Edward Whitehouse

495. Poland's Education and Training: Boosting and Adapting Human Capital (July 2006) Paul O’Brien and Wojciech Paczynski 